\title{
Overdone overkill - the archaeological perspective on Tasmanian megafaunal extinctions
}

\author{
Richard Cosgrove $^{\mathrm{a}, *}$, Judith Field ${ }^{\mathrm{b}}$, Jillian Garvey ${ }^{\mathrm{a}}$, Joan Brenner-Coltrain ${ }^{\mathrm{c}}$, Albert Goede ${ }^{\mathrm{e}}$, \\ Bethan Charles $^{g}$, Steve Wroe ${ }^{\mathrm{d}}$, Anne Pike-Tay ${ }^{\mathrm{h}}$, Rainer Grün ${ }^{\mathrm{f}}$, Maxime Aubert ${ }^{\mathrm{f}}$, Wendy Lees ${ }^{\mathrm{f}}$, \\ James O'Connell ${ }^{\mathrm{c}}$ \\ ${ }^{a}$ Archaeology Program, La Trobe University, Melbourne, VIC 3086, Australia \\ ${ }^{\mathrm{b}}$ Electron Microscope Unit, University of Sydney, NSW 2006, Australia \\ ${ }^{\mathrm{c}}$ Department of Anthropology, University of Utah, Salt Lake City, UT 84112, USA \\ ${ }^{\mathrm{d}}$ School of Biological, Earth and Environmental Sciences, University of New South Wales, New South Wales 2006, Australia \\ e School of Geography and Environmental Studies, University of Tasmania, Hobart, Tasmania 7001, Australia \\ ${ }^{\mathrm{f}}$ Research School of Earth Science, The Australian National University, Canberra, Australia \\ ${ }^{\mathrm{g}}$ Department of Archaeology, The University of Sydney, NSW 2006, Australia \\ ${ }^{\mathrm{h}}$ Department of Anthropology, Vassar College, New York, NY, USA
}

\section{A R T I C L E I N F O}

\section{Article history:}

Received 18 February 2010

Received in revised form

16 May 2010

Accepted 17 May 2010

\section{Keywords:}

Late Pleistocene Tasmania

Megafauna

Dating

Overkill

Prey choice

\begin{abstract}
A B S T R A C T
The reasons for megafaunal extinction in Australia have been hotly debated for over 30 years without any clear resolution. The proposed causes include human overkill, climate, anthropogenic induced habitat change or a combination of these. Most protagonists of the human overkill model suggest the impact was so swift, occurring within a few thousand years of human occupation of the continent, that archaeological evidence should be rare or non-existent. In Tasmania the presence of extinct megafauna has been known since the early twentieth century (Noetling, 1912; Scott, 1911, 1915) with earlier claims of human overlap being rejected because of poor chronology and equivocal stratigraphic associations. More recent archaeological research has not identified any megafauna from the earliest, exceptionally well-preserved late Pleistocene cultural sites. In 2008 however an argument for human induced megafaunal extinctions was proposed using the direct dates from a small sample of surface bone from two Tasmanian nonhuman caves and a museum sediment sample from an unknown location in a cave, since destroyed by quarrying (Turney et al., 2008). Turney et al. (2008) supplemented their data with published dates from other Tasmanian caves and open sites to argue for the survival of at least seven megafauna species from the last interglacial to the subsequent glacial stage.

To investigate the timing of extinctions in Tasmania and examine the latest claims, new excavations and systematic surveys of limestone caves in south central Tasmania were undertaken. Our project failed to show any clear archaeological overlap of humans and megafauna but demonstrated that vigilance is needed when claiming survival of megafauna species based on old or suspect chronologies.

The results of our six-years of fieldwork and dating form the first part of the present paper while, in the second part we assess the data advanced by Turney et al. (2008) for the late survival of seven megafauna species. A model of human prey selection and the reasons for the demise of a range of marsupials, now extinct, are discussed in the third part of the paper.
\end{abstract}

(C) 2010 Elsevier Ltd. All rights reserved.

\section{Introduction}

The demonstration of direct human interaction with extinct fauna in Australia has been elusive. Nowhere are there deep Pleistocene deposits like those of the European record and clear

\footnotetext{
* Corresponding author. Tel./fax: +61 394791424.

E-mail address: r.cosgrove@latrobe.edu.au (R. Cosgrove).
}

associations of artefacts and extinct animals only occur at two sites (Field et al., 2008; Fillios et al., 2010). This has led to intense debate over the stratigraphic integrity of megafaunal remains, associated chronologies and the reasons for their disappearance (Miller et al., 2005; Prideaux, 2004; Roberts et al., 2001; Trueman et al., 2005; Wroe et al., 2004). In Europe the explanations given for late Pleistocene mammal extinctions are climate changes and human impacts (Barnosky et al., 2004; Koch and Barnosky, 2006). In Australia the arguments that propose an 
exclusively human cause for extinctions are based on absolute dating techniques and isotope analyses applied to articulated animal remains and Genyornis newtoni eggshell (Miller et al., 1999, 2005; Roberts et al., 2001), but critically nowhere have these claims demonstrated a clear human-megafauna stratigraphic association. The reasons put forward for this lack of correlation are that the human impact was so swift it did not leave any archaeological trace (Roberts et al., 2001). Although this is seen by some to explain the lack of archaeological evidence, it's been observed that cultural associations are important in supporting the human causation theory (Cosgrove and Allen, 2001; Diamond, 2008: 834; Wroe et al., 2004; Wroe and Field, 2006). This is because the chronology from noncultural sites only shows a coincidence of overlap, not a direct correlation with human hunters and archaeologists remain skeptical of this (Field, 2006: 5). Others believe that direct bone dating in non-human sites overcomes these problems and that this is sufficient to demonstrate human-megafauna overkill (Roberts and Jacobs, 2008: 17). However this does not make it so, it simply shows overlap.

Suggestions by Turney et al. (2008) of human induced megafaunal extinctions in Tasmania have also relied on dating sediment from non-human cave and open sites without much discussion of the Tasmanian archaeological record. Because the geochronological evidence dominates much of the current debate, its uncoupling from the very rich archaeological data (Grayson and Meltzer, 2003), diminishes the range of alternative cultural and palaeoecological explanations for the disappearance of Tasmania's megafauna (Wroe and Field, 2006).

Turney et al. (2008) bring a more precise chronological assessment to the problem by direct bone dating but argue that climatic change had no influence on extinctions. They state that their megafaunal dating program shows survival of some species until human arrival, although in their analysis only one subadult species, Protemnodon anak (c. $60 \mathrm{~kg}$; Turney et al., 2008: 12152) is dated to the period of argued overlap with people. They also believe that their evidence supports a model of over hunting of up to seven megafaunal species soon after people arrived via the Bassian Landbridge. This is similar to arguments made for the Australian mainland megafauna where humans have been implicated in their rapid disappearance due to overkill. However there are a number of significant problems with their Tasmanian data and these are discussed in the second part of this paper.

As Tasmania was connected by a narrow landbridge c. 40,000 calBP that allowed humans entry after this time, Tasmania provides an ideal 'laboratory' to test the impact of humans on a range of animal species, including megafauna. The two oldest recorded human sites are Warreen Cave dated to $34,790 \pm 510 \mathrm{BP}$ $(39,906 \pm 879$ calBP $)$ and Parmerpar Meethaner dated to $33,850 \pm 450 \mathrm{BP}(39,310 \pm 1151 \mathrm{calBP})$ and their ages fit comfortably with access via the Bassian landbridge (Fig. 1). However, analysis of over 950,000 bones from the eight welldated and stratigraphically controlled late Pleistocene archaeological sites from western, central and northern Tasmania (Fig. 1) have not identified megafauna as part of human prey or any extended period of overlap with them (Cosgrove et al., 1990; Cosgrove, 1999; Cosgrove and Allen, 2001; Garvey, 2007). These span the time period from $13,000 \mathrm{BP}$ to $35,000 \mathrm{BP}$. Indeed only six fragments of bone attributed to the largest extant macropod, Macropus giganteus giganteus have been recorded in the entire eight Southern Forests faunal assemblages (Garvey, 2006; McWilliams et al., 1999). Because these are large bones found well preserved in limestone cave deposits it's unlikely that their low number is due to taphonomic effects. This is discussed further below.

\section{New surveys, excavation and dating}

The first part of the paper focuses on the results of excavation, cave survey and bone dating between 2003 and 2009 at the nonhuman sites of Titan's Shelter (JF97), no-name cave (JF155), Ultimate Cave (JF168) and Emu Cave (JF154). All four are limestone caves in the Florentine River valley (Fig. 2). Our aims are to:

a) Describe the results of these cave surveys and excavation at Titan's Shelter in the Florentine River valley.

b) Present the results of AMS and ESR dating of collagen and teeth derived from Macropus giganteus titan and Simosthenurus sp found as a result of the above fieldwork.

c) Review the evidence for the presence of seven megafaunal species at human arrival (Turney et al., 2008).

d) Discuss the implications of these results for humans as agents of megafaunal extinction in Tasmania.

\section{Study area}

The Florentine River valley (Fig. 2) has been the subject of palaeoentological research since the 1970s (Goede and Murray, 1977: 9; Murray et al., 1980: 151-2). A claim for the survival of M. giganteus titan until 14,000 BP was later retracted in 1985 when ESR dating showed that some bones were much older than the deposit in which they lay and that the charcoal was intrusive (Goede and Bada, 1985: 160; Goede and Murray, 1979: 52). Other megafaunal elements recorded from the valley included a possible Zygomaturus tooth, a Sthenurine maxilla, $P$. anak and M. giganteus titan metatarsals.

An ESR date from Titan's Shelter site G (now G1) had returned an age of 27,000 BP while an aspartic acid date of 40,000 BP was obtained from the same location (Figs. 3 and 4). At site F an ESR date of 49,000 BP was obtained (Goede, 1998: 151; Goede and Bada, 1985: 160). The range of ages suggests a complex taphonomic history in this cave.

Recent improvements in dating techniques and protocols for the extraction of collagen provided an opportunity to revisit the question of the age of large mammal remains in the Florentine River valley.

\subsection{Titan's shelter}

\subsubsection{Excavation methods}

Our team undertook systematic archaeological investigation between 2004 and 2007 at Goede and Murray's (1979) site G, while bone samples were excavated from a small remnant deposit at site F (Figs. 3 and 4). Two new excavations designated G2 and G3 were located to the northwest and southeast of the original pit. Square $\mathrm{G} 2$ was a $50 \mathrm{~cm} \times 50 \mathrm{~cm}$ while $\mathrm{G} 3$ was $25 \mathrm{~cm} \times 25 \mathrm{~cm}$. Both squares had very similar stratigraphy and contents. The following description relates to both squares.

The excavation proceeded in $5 \mathrm{~cm}$ spits to a depth of c. $90 \mathrm{~cm}$. There were three main layers (Fig. 5). The G2 square was located under a lintel of flowstone to give excavators access to deposit without the need to break through the thick overlying calcium carbonate. Square G3 was located at the southeast corner of the original $\mathrm{G}$ pit.

Layer 1 consisted of a friable, unconsolidated brown cave earth (7.5YR 4/4). No brown earth was found under the flowstone, confirming that the brown cave earth originated from up-slope, overlying layer two, supporting the stratigraphic interpretation originally described by Goede and Murray (1979). Whole bone was recovered from this layer, including an upper right Thylacoleo carnifex incisor, a $M$. giganteus titan right mandible, two 4th metatarsals and 


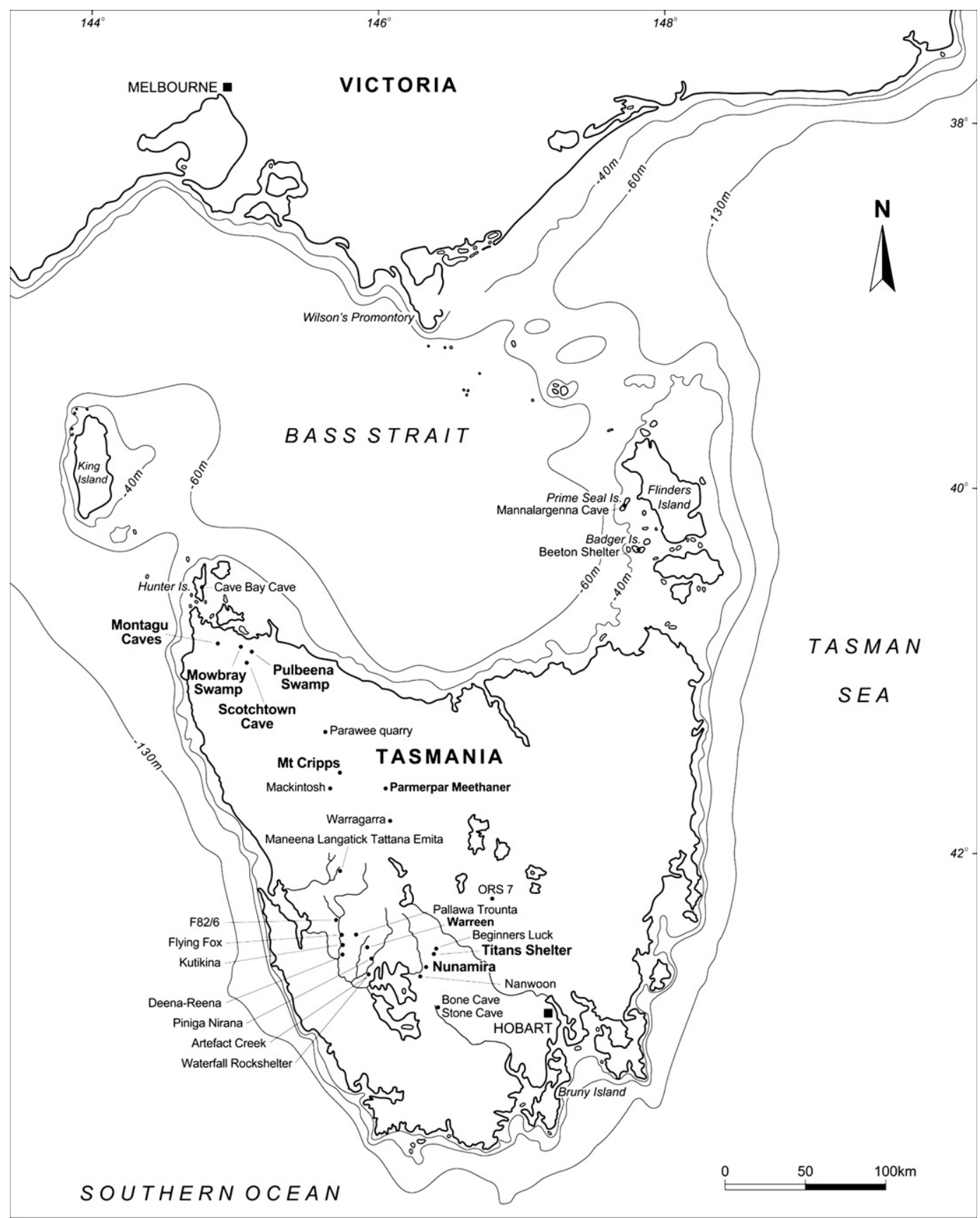

Fig. 1. Distribution of late Pleistocene archaeological sites. Names in bold refer to the megafauna sites mentioned in the text.

a Simosthenurus sp. right phalanx (Figs. 6-8). Soil conditions were excellent for the preservation of bone with a $\mathrm{pH}$ of 8.5.

Layer 2 was a dark, yellowish brown, silty clay soil (10YR 4/4). This layer contained abundant and highly fragmented bone in an unconsolidated matrix, quite different from the mainly complete bone in Layer 1 . Some limestone nodules were apparent throughout and in some places had begun to decompose. The pH was 8.5.

Layer 3 was a slightly more consolidated silty clay layer with some charcoal but fewer bone fragments. The colour was dark brown (10YR 4/4) with a $\mathrm{pH}$ of 9.0 .

\subsubsection{Fauna}

Bones from G2 were collected from the $7 \mathrm{~mm}$ and $3 \mathrm{~mm}$ sieves and analysed (Table 1). Four hundred and twenty three bones were identified to 18 mammal species, with nine rodents and four birds. A further 75 bones remained unidentified (Table 1).

Both extant and extinct species were recovered within the deposit and suggested that the valley contained a wide variety of mammals during the late Pleistocene including the extinct Simosthenurus, the large browsing kangaroo (Goede and Murray, 1979). Our excavation revealed a range of species that included $T$. carnifex and Sarcophilus laniarius, the larger form of the Tasmanian devil (Table 1 ). The suite of large to medium sized herbivores such as M. giganteus titan, Simosthenurus sp., M. giganteus giganteus, Macropus rufogriseus, Vombatus ursinus and Thylogale billardierii suggests the valley vegetation consisted of open sclerophyll woodland and grassland at these times. Large 


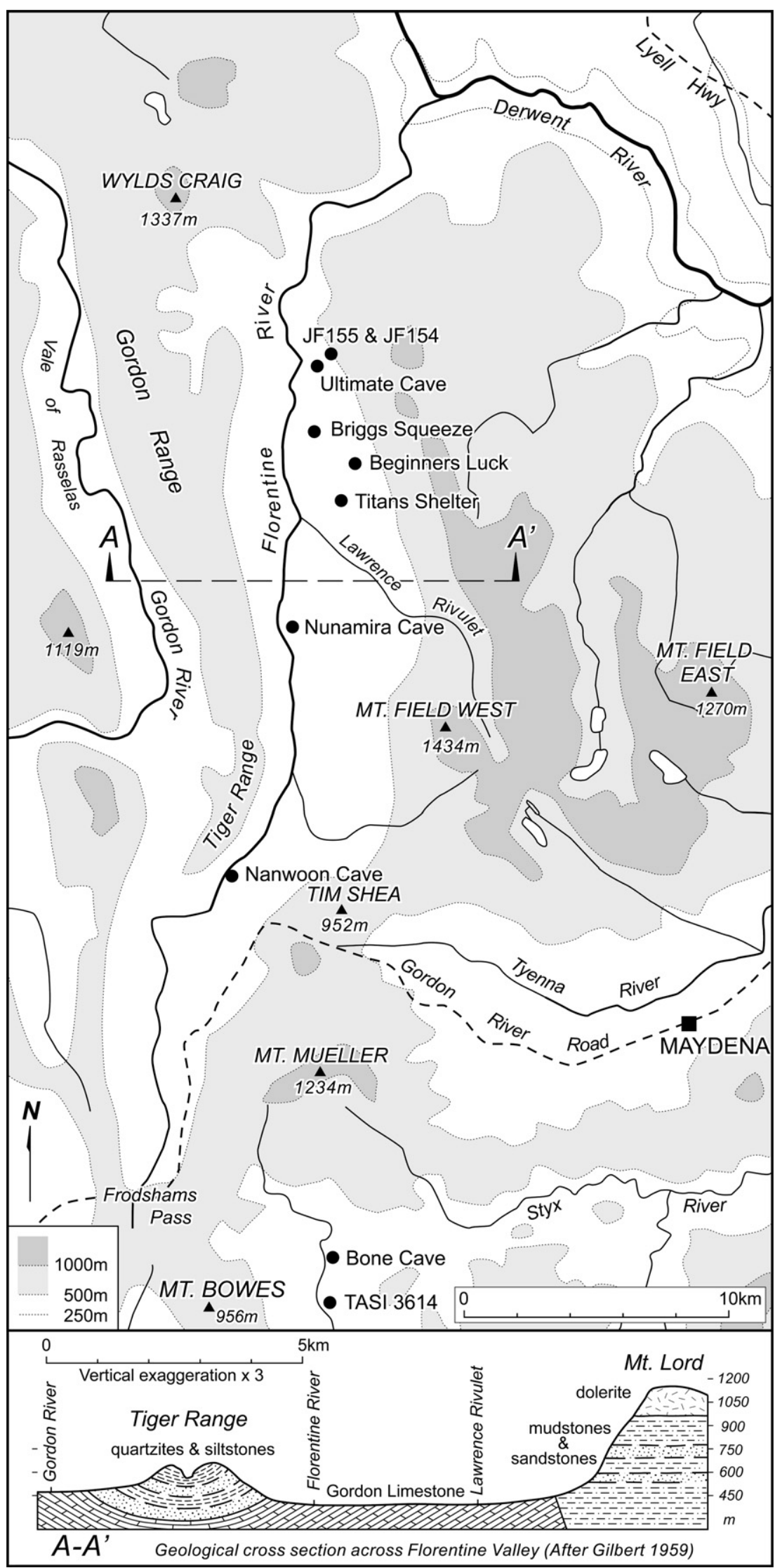

Fig. 2. The Florentine River valley in south central Tasmania showing altitudinal cross-section and the major archaeological and megafauna sites. 


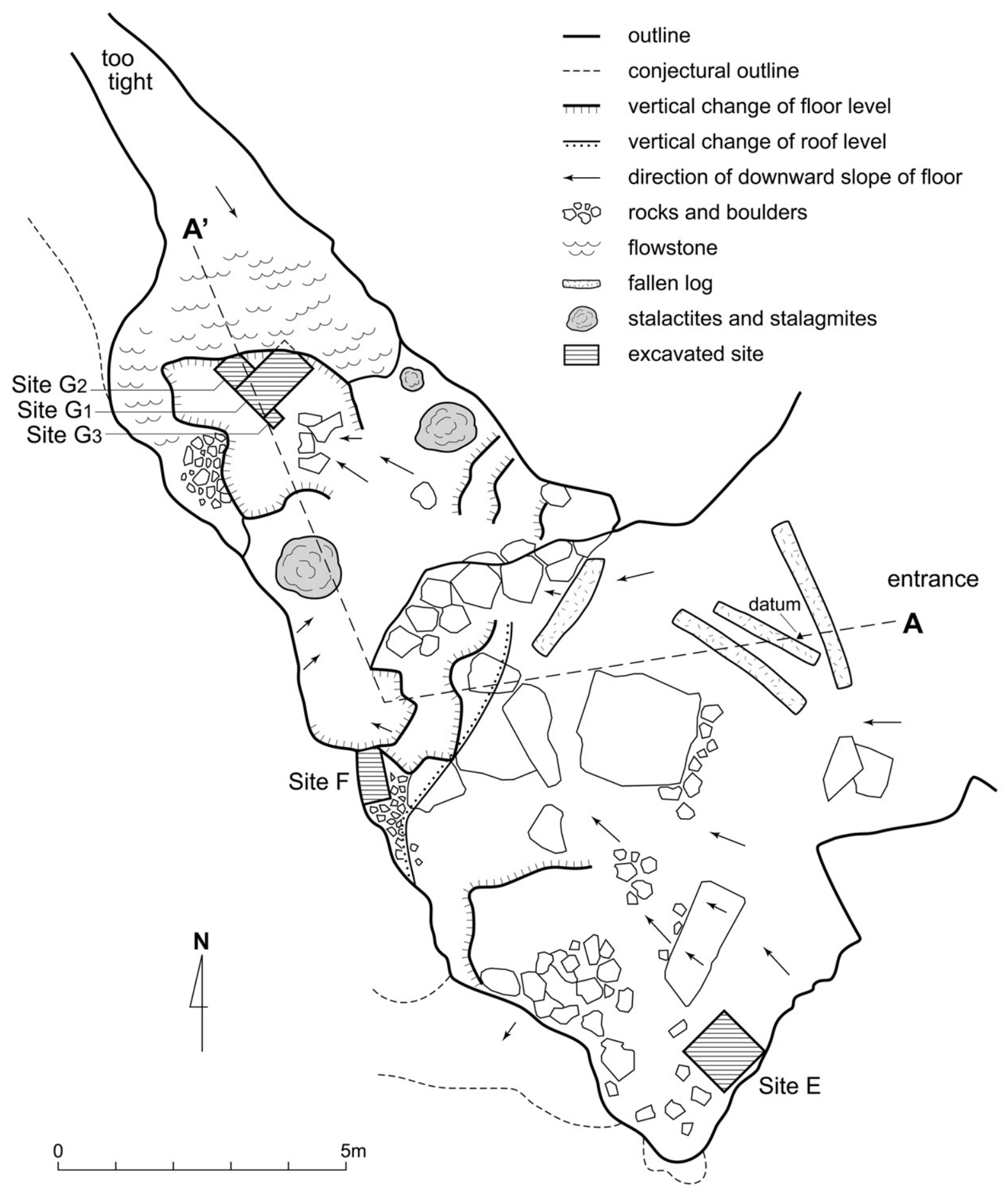

Re-excavated February 2004

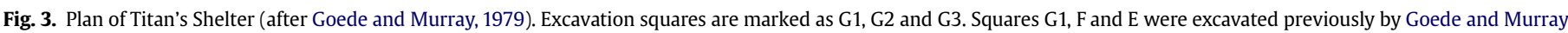
(1979).

carnivores such as T. carnifex, S. laniarius and Thylacinus cynocephalus indicate a sufficiently abundant and diverse animal community to support non-human hunters and scavengers. Medium to small carnivores such as Dasyurus, and Sarcophilus probably preyed on the smaller tree and ground dwelling animals such as Pseudocheirus peregrinus, and Potorous tridactylus. The presence of other smaller animals and birds indicate that owls may have used the cave site as a roost.

\subsubsection{Chronology}

Bone of two extant species, wallaby (M. rufogriseus) and wombat (V. ursinus.), from Warreen cave, further west in the Maxwell River valley (Allen, 1996: 153), from levels radiocarbon dated to $30,210 \pm 300 \mathrm{BP}$ (Beta-42059; ETH-8501) and 34,790 $\pm 510 \mathrm{BP}$ (Beta-42122B; ETH-7665B) were submitted to the radiocarbon laboratory at AINSE, Sydney, as control samples. The results of the pair-matched bone collagen analyses reveal a good correlation with 


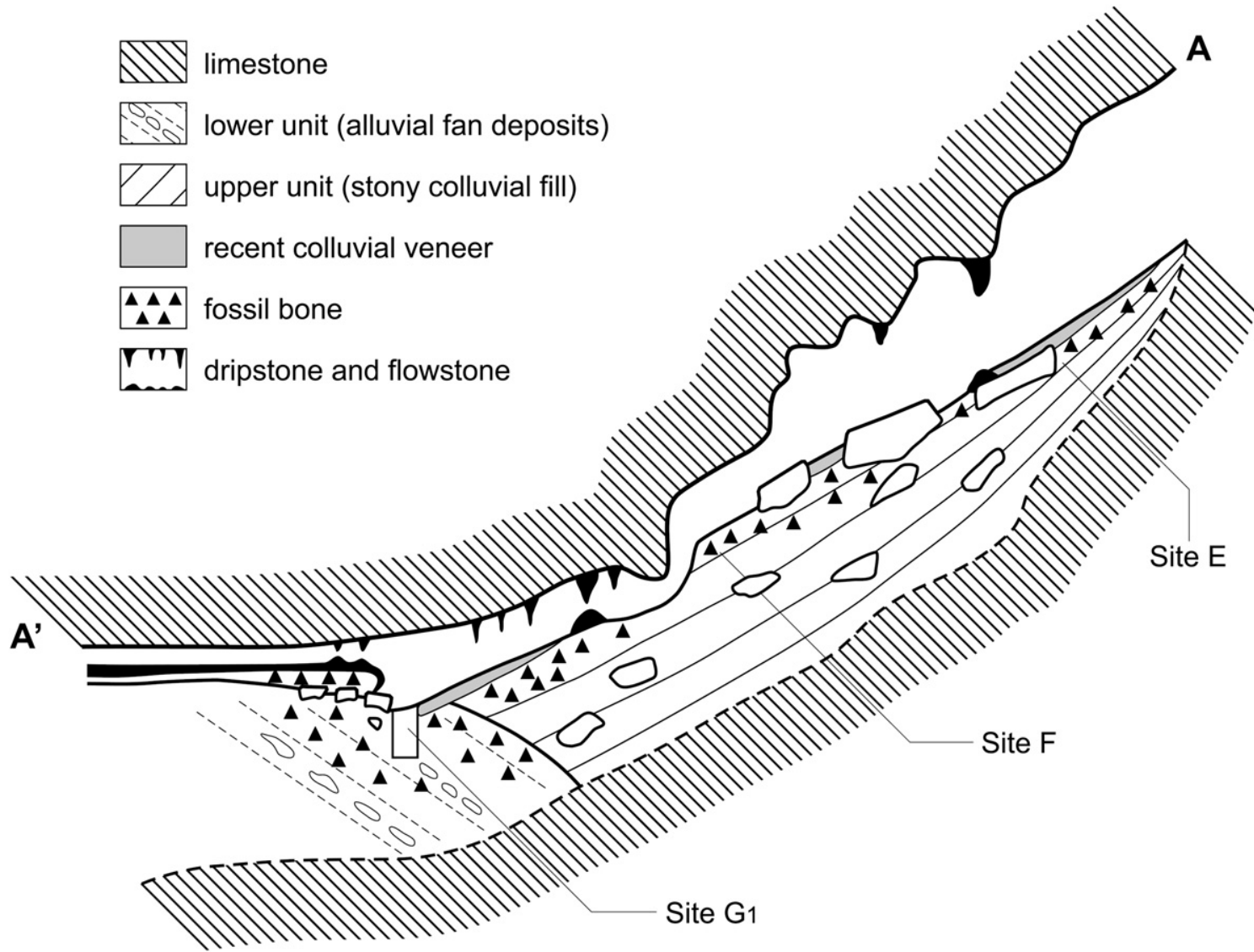

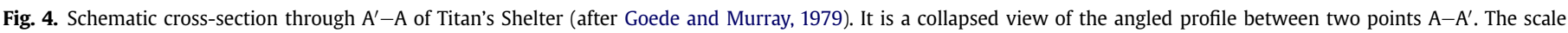
should be read from Fig. 3 .

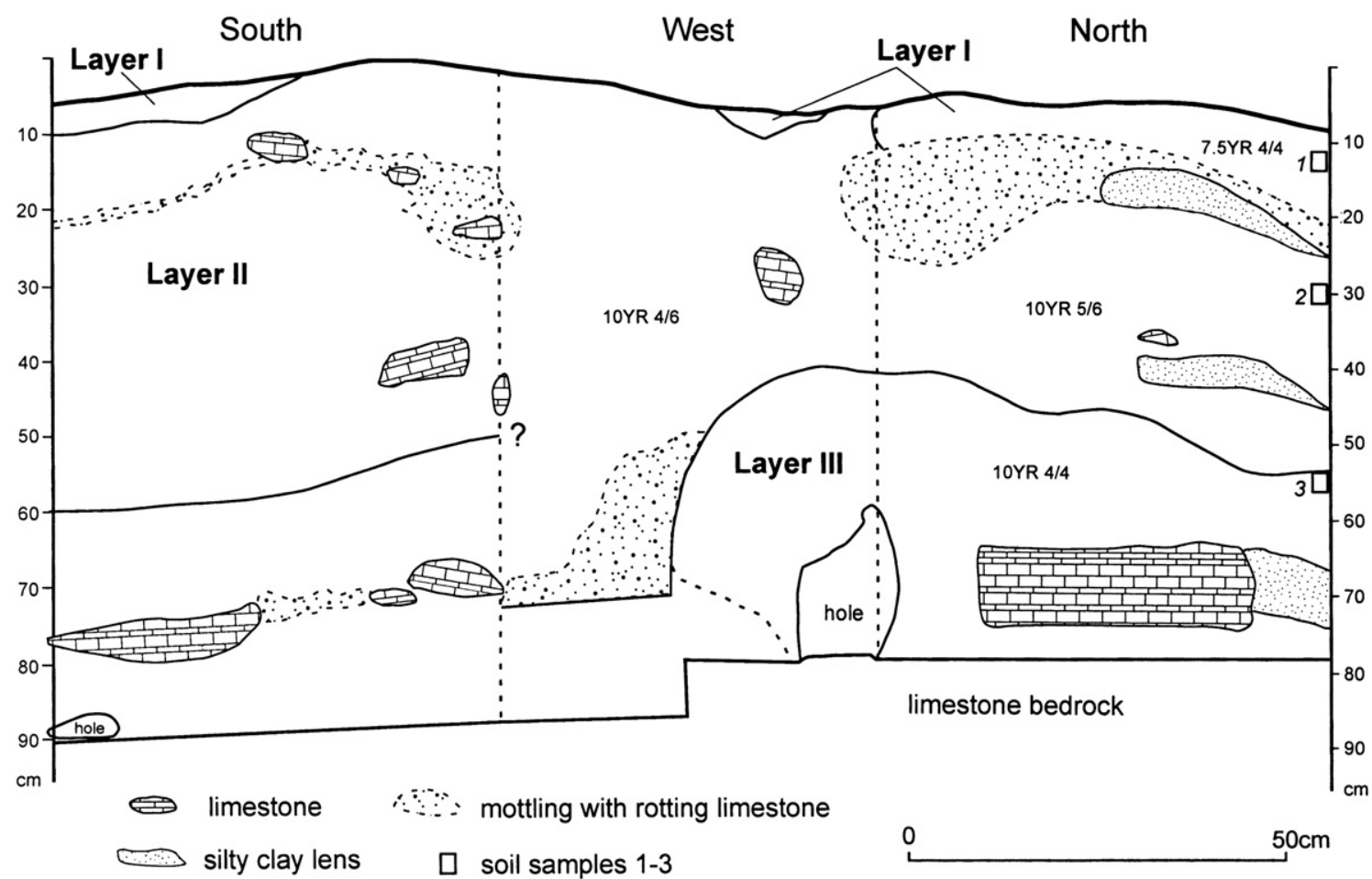

Fig. 5. Stratigraphic drawing of square G2 and its three layers. Macropus giganteus titan, Simosthenurus sp. and Thylacoleo carnifex were found within Layer 1. 

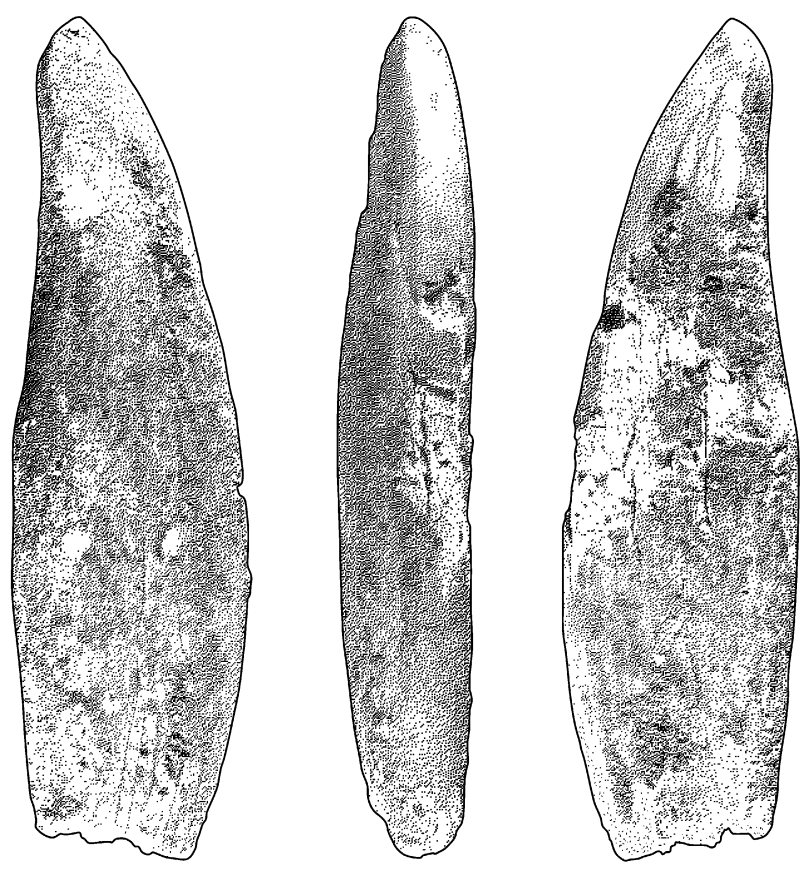

0

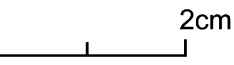

Fig. 6. Thylacoleo carnifex upper right incisor shown in three views.

the charcoal dates of $31,660 \pm 250$ (OZF415) \& $30,610 \pm 350$ (OZF416) respectively (Table 2 ). Four bones of $M$. giganteus titan from Titan's Shelter (JF97) were then submitted for dating. One sample (LL580/OZG073) came from a metatarsal IV bone that was excavated in 1979 from the uppermost layers at site $\mathrm{F}$, within a surface band of bone rich sediment $25 \mathrm{~cm}$ thick by Goede and Murray (1979). Three other foot bones were excavated during the present study; two from site F (LL1177/OZI214; LL581/OZF761) from the uppermost layer and one from site G2 from Layer 1 (OZI215) (Table 3 ). The latter bone did not contain any collagen and was too degraded to process. To assess any age differences between filtered and non-filtered collagen treatments, two samples (LL1177/OZI214 and LL581/OZF761) were pair-matched at Lawrence Livermore and Oxford laboratories. The results of this analysis showed a difference of 2650 and 1380 years respectively. Despite the fact that the
Oxford age assays included the ultrafiltration technique, the nonfiltered Lawrence Livermore National Laboratory dates are older. At present we have no explanation for this discrepancy but we have used the older Livermore ages in calculating the relationships between the human and $M$. giganteus titan chronologies as they suggest a more complete removal of younger carbonates. Protocols for pre-treatment are given in Appendix A.

Nevertheless the central tendency of dates from Livermore and AINSE clearly demonstrate the presence of $M$. giganteus titan in the valley between $40,486 \pm 874$ calBP and $42,214 \pm 404$ calBP. We note Turney et al. (2008) have similar dates for $P$. anak at Titan's Shelter of c. 44,000 BP.

Given the degradation of collagen in the bone from site G2, a tooth (2379A/2379B) from the M. giganteus titan mandible was submitted for ESR analysis to the Australian National University (Table 4). This mandible was stratigraphically equivalent to the Thylacoleo upper incisor and a right phalanx of Simosthenurus. An age of $53,000 \pm 4000$ was obtained for the tooth. Because the two other species are in close stratigraphic relationship, we assume a similar age. The protocols for this analysis are presented in Appendix B.

\subsection{Un-named cave [JF155]}

\subsubsection{Survey and collection methods}

The site is located $6 \mathrm{~km}$ north of Titan's Shelter, has a vertical entrance and a steep pitch of over $12 \mathrm{~m}$ to the cave floor (Fig. 9). This cave was originally inspected by one of us (A.G.) in October 1978 after J. Parker discovered it in September of the same year. Goede collected non-megafaunal bone samples embedded in a small talus including $M$. rufogriseus bones and possibly $M$. giganteus giganteus for dating on the 21st October 1978 and 15th November 1978. Bone samples were dated by aspartic acid to 30,000 BP and by ESR to 97,000 BP (Goede and Bada, 1985).

Cosgrove, Garvey and Serena Benjamin further surveyed the cave in 2007 when exploration revealed a brown cave earth deposit containing in situ megafauna bone in a very precarious location at the 'Roof Site' at the top of a 'chimney' near the cave roof (Fig. 9). A Simosthenurus sp. femur, and a possible pelvis and rib from the same species were carefully recovered from the brown earth for dating.

\subsubsection{Chronology}

The rib and a sample of femur were submitted for analysis. Originally these returned ages of 50,600 \pm 3000 and 50,000 \pm 3000 respectively but because they were very close to an infinite age, the
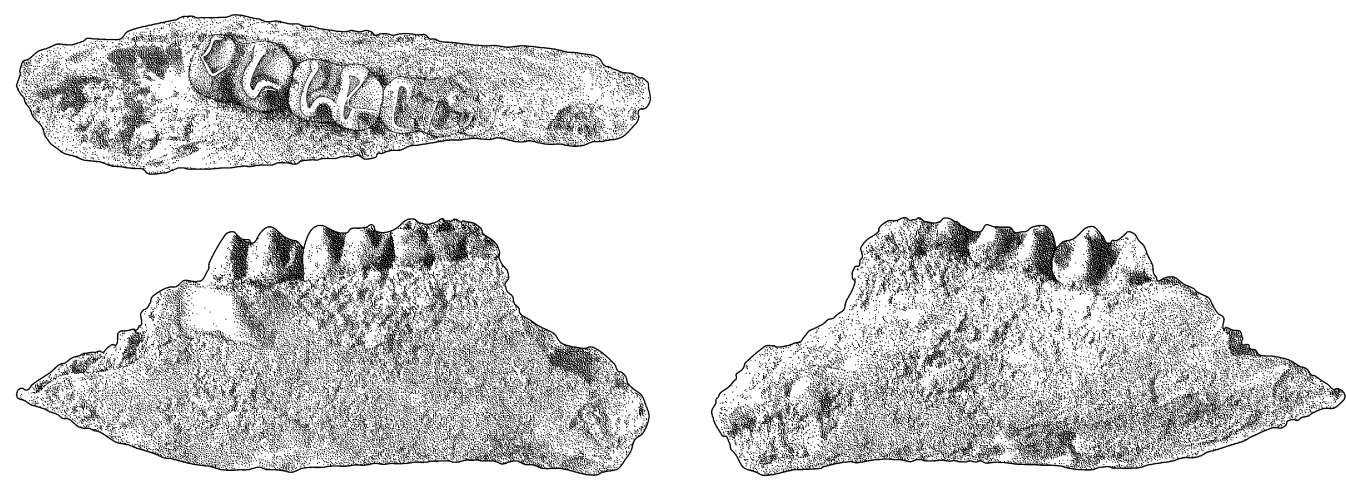

0 $2 \mathrm{~cm}$

Fig. 7. Macropus giganteus titan right mandible shown in three views. 

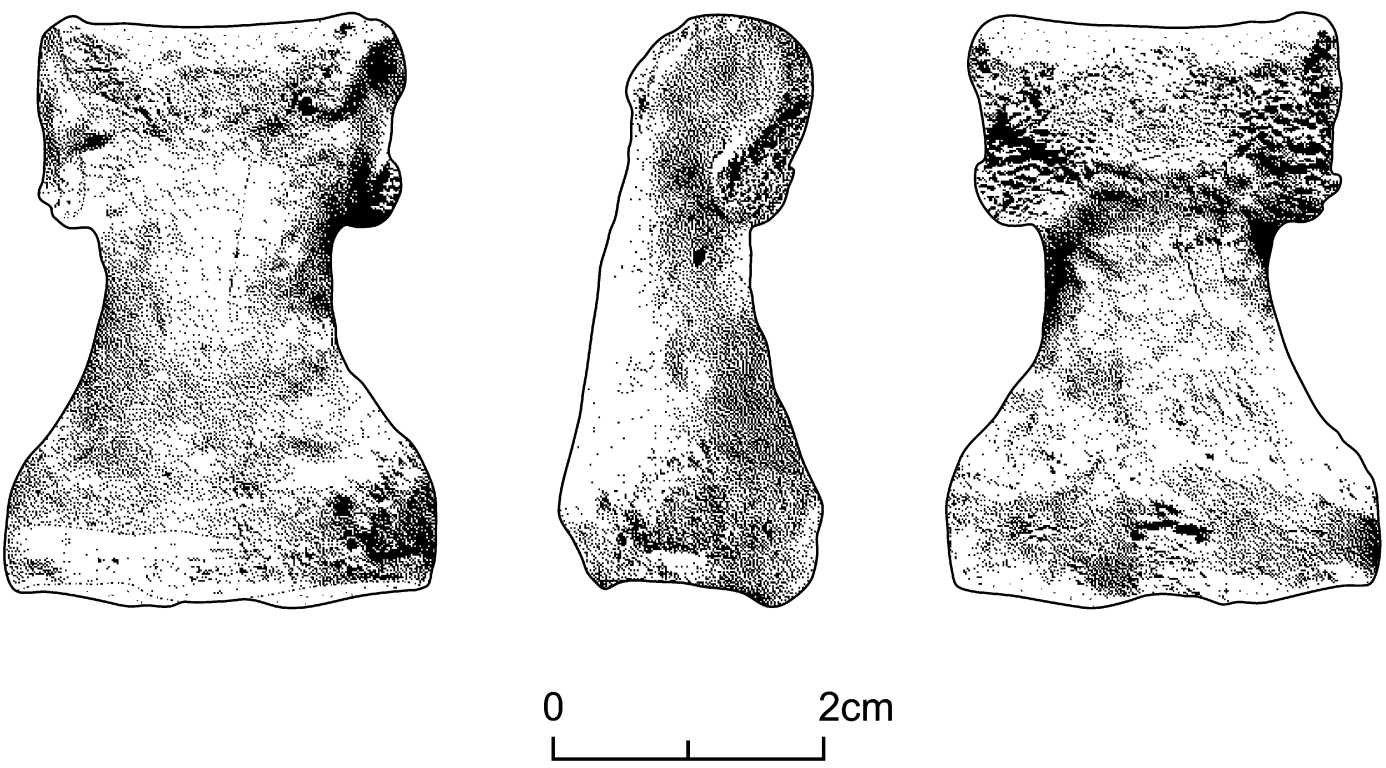

Fig. 8. Simosthenurus sp. right phalanx shown in three views.

Livermore Laboratory re-ran the samples. The final ages assayed are $44,700 \pm 3300 \quad(49,121 \pm 3003 \mathrm{calBP})$ and $>46,200$ uncalBP respectively (Table 5). These ages lie well outside the range of known human occupation in the Florentine River valley.

\subsection{Emu cave [JF154]}

\subsubsection{Survey and collection methods}

This cave is located in the upper part of the Florentine River valley about $100 \mathrm{~m}$ north of JF155 and was discovered in 1978. It has a horizontal entrance with very narrow (c. $45 \mathrm{~cm})$ squeeze into

Table 1

The range of species excavated from Titan's Shelter, square G2 and their frequency (NISP).

\begin{tabular}{|c|c|c|c|}
\hline Species & Common name & NISP & Status \\
\hline Thylacoleo carnifex & Marsupial lion & 1 & Extinct \\
\hline Simosthenurus sp. & Sthenurine kangaroo & 5 & Extinct \\
\hline Macropus giganteus titan & $\begin{array}{l}\text { Larger Pleistocene eastern grey } \\
\text { kangaroo }\end{array}$ & 12 & \\
\hline Macropus giganteus & Eastern grey kangaroo & 24 & Extant \\
\hline Macropus rufogriseus & Bennett's wallaby & 99 & Extant \\
\hline $\begin{array}{l}\text { Unidentified Macropod } \\
\text { sp. }\end{array}$ & Macropod & 106 & \\
\hline Thylogale billardierii & Tasmanian Pademelon & 10 & Extant \\
\hline Vombatus ursinus & Common Wombat & 3 & Extant \\
\hline Dasyurus viverrinus & Eastern Quoll 'Native Cat' & 20 & Extant \\
\hline Dasyurus maculatus & Spotted-tailed Quoll 'Tiger Cat' & 3 & Extant \\
\hline Sarcophilus harrisii & Tasmanian Devil & 9 & Extant \\
\hline Sarcophilus laniarius & Larger Pleistocene Tasmanian Devil & 5 & \\
\hline $\begin{array}{l}\text { Thylacinus } \\
\text { cyanocephalus }\end{array}$ & Tasmanian Tiger & 3 & Extinct \\
\hline Pseudocheirus peregrinus & Common Ringtail possum & 2 & Extant \\
\hline Potorous tridactylus & Long-nosed Potoroo & 1 & Extant \\
\hline Mastacomys fuscus & Broad toothed rat & 28 & Extant \\
\hline Pseudomys higginsi & Long tailed mouse & 1 & Extant \\
\hline Antechinus sp. & Antechinus & 2 & Extant \\
\hline Rodent & Rodent & 9 & \\
\hline $\begin{array}{l}\text { Ornithorhynchus } \\
\text { anatinus }\end{array}$ & Platypus & 1 & Extant \\
\hline Bird & Bird unidentified & 4 & \\
\hline Unidentified & Unidentified to species & 75 & \\
\hline Total & & 423 & \\
\hline
\end{tabular}

the main chamber. It was further explored in 2007. No cultural remains were noted but megafauna remains were discovered.

\subsubsection{Fauna}

One of us (A.G.) collected 12 pieces of emu bone (one cranial fragment and 11 pieces of long bone) from the upper layer of brown cave soil in 1978. The presence of this species indicates an open grassy environment when it occupied the valley. In 2007 further inspection identified a complete skull of a Simosthenurus sp. embedded in the wall of a narrow passage leading into the main chamber of the cave. A portion of the occipital bone that had been broken off was collected and a sample submitted for dating.

\subsubsection{Chronology}

The collagen in this bone was dated to $>45,400 \mathrm{BP}$ and again is outside the earliest known evidence of human occupation in Tasmania (Table 5).

\subsection{Ultimate cave [JF168]}

\subsubsection{Survey methods}

Peter Murray identified and collected an M. giganteus titan pelvis from the surface of Ultimate Cave (JF168) after its discovery in 1978. Although the cave is yet to be fully described, it has a very tight and awkward vertical entrance that drops down $3 \mathrm{~m}$ into a small horizontal cave system. Further inspection in 2007 revealed a jumble of bones exposed on the surface, some of them cemented to the floor of the chamber.

\subsubsection{Chronology}

A bone sample from the pelvis (LL579/OZG072) was assayed to $39,530 \pm 580 \mathrm{BP}($ calBP $43,506 \pm 635)$ (Table 3$)$.

\section{Evidence for late-surviving megafauna}

In the second part of the paper, we turn our attention to an assessment of the fossil bone deposits used by Turney et al. (2008) to argue for the survival of seven megafauna species from the last interglacial to the subsequent glacial stage. A close re-examination of their original stratigraphic interpretation, chronology and our 
Table 2

AINSE test series on bone collagen and pair matched 14C dates from Warreen Cave.

\begin{tabular}{|c|c|c|c|c|c|c|c|c|c|c|}
\hline Site & Code (Field code) & Species & Element & Weight & $\mathrm{N} \%$ & $\mathrm{C} / \mathrm{N}$ & $13 C$ & \% Modern Carbon & AMS Bone Age & Charcoal $14 \mathrm{C}$ \\
\hline Warreen Cave & OZF415 (WC/A/11/16 ID 91) & Macropus rufogriseus & Tibia & $4.2 \mathrm{~g}$ & 6.50 & 3.50 & -21.75 & 1.94 & $31,660 \pm 250$ & $30,210 \pm 300$ \\
\hline Warreen Cave & OZF416 (WC/A/18 ID 84) & Vombatus ursinus & Proximal femur & $5.0 \mathrm{~g}$ & 11.5 & 3.33 & -20.26 & 2.21 & $30,610 \pm 350$ & $30,210 \pm 300$ \\
\hline
\end{tabular}

identification of the erroneous attribution of an OSL date to cave deposits reveal some misplaced confidence in the strength of the evidence.

\subsection{Scotchtown cave}

Based on a single OSL date of $56 \pm 4 \mathrm{ka}$, Turney et al. (2008) assume that all seven megafauna species identified at the now destroyed Scotchtown Cave are of similar age. This conclusion is unjustified because of the manner in which the bones and sediments were found, collected and stored. Mining activity in 1942 exposed this cave in a limestone quarry that contained between $182 \mathrm{~cm}$ and $70 \mathrm{~cm}$ of brown cave earth (Gill and Banks, 1956; Scott, 1942a,b). The cave was $274 \mathrm{~m}$ long and $18 \mathrm{~m}$ high before destruction by quarrying. Mr E.G.O. Scott collected fragmented bones from the deposits exposed in the cave. Although no field notes or stratigraphic drawings are known, Scott's correspondence sheds some light on the bone collection. The condition of the bone was highly fragmented and probably disturbed. He says in a letter to the then director of the Australian Museum, Sydney, Dr A. B. Walkom;

As I have already said, however, the material was in an extremely disappointing state. There was, indeed plenty there; but everything was so badly mutilated - either as a result of the activities of a possible carnivorous haunter (sic) of the cave, or as the outcome of the collapsing of the roof - that it was almost impossible to secure a single bone (other than vertebrae) intact. Long bones were almost invariably in splinters, and, even if a good deal of the bone was visible in situ (sic), as sometimes happened, the specimen fell into pieces as soon as it was touched. As might have been expected, teeth and lower jaws had survived; but even lower jaws were in a bad state. We obtained in all about forty mandibular rami, but not a single one of these was perfect being commonly about one-third, or less, complete (E.O.G. Scott letter to A.B. Walkom, 21st April 1942).

The sediment sample that provided the Turney et al. (2008) date came from a portion of un-provenanced cave sediment containing unidentified bone fragments stored in a museum cabinet (Craig Reid, Queen Victoria Museum, personal communication) and its location relative to the other bones and sediment is unknown. Turney et al. (2008) found no collagen for dating in the bones presumably because of their badly eroded condition.

It is doubtful that the OSL age of $56 \pm 4$ ka dates all the megafauna bones as assumed by Turney et al. (2008). Indeed the origin of the bone is not known - there is only a supposition made by Scott that the bones might have been brought in by a carnivore or fragmented by roof collapse. No taphonomic analysis was undertaken to establish whether the bones were from local animal pit falls or deposited there from another location via mechanical or fluvial transport. It is clear that the vectors of bone accumulation are not known. As well, the deposit was possibly disturbed as noted by Scott in his 1942 letter.

\subsection{Mowbray swamp}

In Table 1 (Turney et al., 2008), one species of Zygomaturus trilobus is associated with an age of $>37.8 \mathrm{ka}$.
E.C. Lovell, a farmer discovered bones in Mowbray Swamp, $5 \mathrm{~km}$ southwest of Smithton (Fig. 1). All the fossil bones come from the bottom of the peat (E.C. Lovell pers. comm. to Gill and Banks, 1956: 20). Two specimens of $Z$. trilobus (Nototherium) were located, one collected by Lovell, the other excavated by Gill and Banks (1956). Both were located at a depth of $1.83 \mathrm{~m}$ below the surface, overlain by 'whitish sand' at $1.22 \mathrm{~m}$ suggesting two periods of peat accumulation. Peat was collected by Gill and Banks above the band of 'whitish sand' between 0.61 and $1.20 \mathrm{~m}$ and dated to $>37,760 \mathrm{BP}$ (Y 148/2). On the basis of three lines of evidence however, Gill and Banks (1956: 28) date the initial age of the peat accumulation and associated megafauna to the interglacial period of MIS stage 5 because:

a) All the megafauna bones were found at the bottom or base of the peat,

b) The deposit contained a layer of calcium carbonate suggesting to them a period of open water,

c) Pollen evidence show species adapted to open grassy woodlands.

Although no direct age for the bones or precise stratigraphic locations were obtained, they concluded that climatic conditions must have been wet enough to form extensive peat bogs but dry enough to support open woodlands. This interpretation has subsequently been confirmed by Colhoun (1982) at nearby Pulbeena Swamp where pollen sequences between c. 35,000 BP and c. $65,000 \mathrm{BP}$ have been interpreted as showing the presence of forest, grassland and shrubs. Both Pulbeena and Mowbray Swamps have similar pollen and biostraigraphic zones (Colhoun, 1982). Further, additional work by van de Geer (Colhoun, 1982: 119) at Mowbray Swamp indicate that the sands noted by Gill and Banks (1956) are believed to be between $>75,000 \mathrm{BP}$ and $<130,000$ years old. On this basis, the age of $Z$. trilobus bones are probably $>75,000 \mathrm{BP}$. It is possible that these animals became extinct well before human arrivals.

\subsection{Pulbeena swamp}

Palorchestes azael is dated to $>54 \mathrm{ka}$ and included in Turney et al. (2008, Table 1). This specimen was found at a depth of $2.30 \mathrm{~m}$ below the surface, aged by association with a piece of wood to $54,000+11,000 /-4500$ (GrN 7322) (Banks et al., 1976; Colhoun, 1982: 118). This assay exceeds the background limit for conventional radiocarbon dating and must be considered an absolute minimum only. Warnings on the use of individual $14 \mathrm{C}$ wood dates of this magnitude have been made previously by one of the authors of the Turney et al. (2008) paper (Colhoun, 1986). No evidence for this species later survival has been recorded in any of the fossil sites and it's possible it went extinct before human arrival.

\subsection{Titan's shelter}

The collagen date from the Protemnodon reported by Turney et al. (2008, Table 1) of 44,000 BP is from site G, the lowest level of the cave. Although Simosthenurus is associated with this age in their Table 1, there is no collagen date reported by Turney et al. 


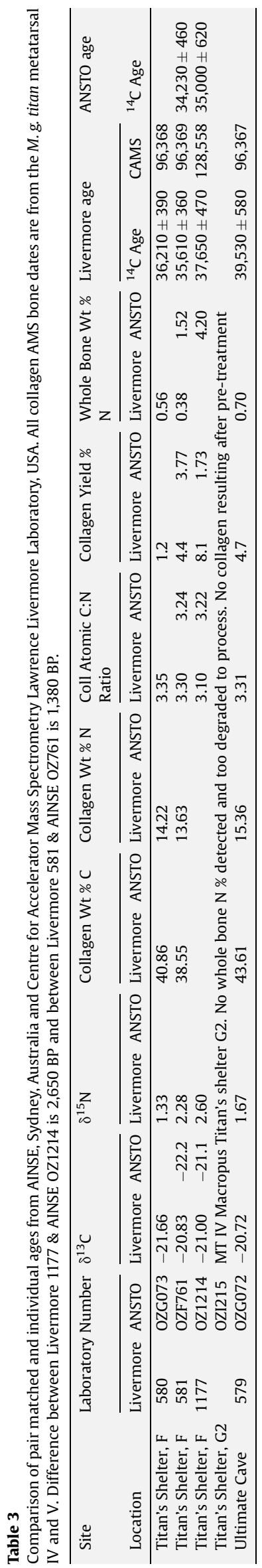

Table 4

ESR results, ANU, Canberra on Macropus giganteus titan M3 molar extracted from mandible, Titan's Shelter, square G3, Layer 1. It dates the Thylacoleo carnifex (G2, spit 1) and Simosthenurus sp. (G2, spit 5) by stratigraphic association in Layer 1 brown earth to the same time period.

\begin{tabular}{|c|c|c|c|c|c|}
\hline Site & Sample & Species & Site & Location Spit & Age \\
\hline Titan's & Shelter, G3 & $2379 A$ & & & $\begin{array}{l}\text { Macropus } \\
\text { giganteus titan }\end{array}$ \\
\hline \multirow[t]{2}{*}{ Titans } & Shelter & G3 & & & \\
\hline & & & 5 & $\begin{array}{l}55,000 \\
\pm 3000\end{array}$ & \\
\hline Titan's & Shelter, G3 & 2379B & & & $\begin{array}{l}\text { Macropus } \\
\text { giganteus titan }\end{array}$ \\
\hline \multirow[t]{3}{*}{ Titans } & Shelter & G3 & & & \\
\hline & & & 5 & $\begin{array}{l}51,000 \\
\pm 3000\end{array}$ & \\
\hline & $\begin{array}{l}\text { This results in a best } \\
\text { estimate of } 53,000 \\
\pm 4000\end{array}$ & & & & \\
\hline
\end{tabular}

(2008) for Simosthenurus and therefore there is no basis for assuming a similar age. The stratigraphic location of this specimen is unclear. Prideaux (2004) is referenced as the source for this sample but his Table 44 and fossil site descriptions only shows that it comes from Titan's Shelter, not a specific stratigraphic location (Prideaux, 2004: 98, 334). Goede and Murray (1979) note a single Sthenurus (Simosthenurus) metatarsal IV coming from site $\mathrm{F}$ and three isolated teeth located in site G. The lower unit of the latter site is interpreted as being water sorted and transported material (Goede and Murray, 1979: 49). Three subsequent ages for site $G$ of 27,000 (ESR), 40,000 (aspartic acid date) and 14,310 (14C) were obtained by Goede and Bada (1985). These dates are consistent with charcoal intrusion and sediment reworking in the lower site $G$ unit as originally suggested (Goede and Bada, 1985). The age and provenance of the Simosthenurus specimen is therefore unknown.

\subsection{Un-named cave (JF155)}

The 'Un-named cave JF155' (Turney et al., Table 1) is not, in fact JF155. There are several reasons for believing this. Firstly Goede recovered only the bones of extant animals as described above from JF155. These were stored in the Tasmanian Museum and Art Gallery (TMAG).

Secondly the TMAG database show that the JF155 (15/11/79) museum record is immediately above the record for Breccia Ridge Cave (JF109; no date) that contains the megafauna. It is possible that this led to an erroneous site name substitution by Turney et al. (2008).

Thirdly JF155 is a large limestone cave (Fig. 9), whereas Breccia Ridge Cave is described as,

Located on ridge on SW side of Settlement road about $400 \mathrm{~m}$ past Beginner's Luck and on opposite side of road. Discovered and explored in 1975. Sloping entrance leads to a single chamber with collapse hole in cave fill in floor. Small passage to left continues approx. 10 metres after two tight squeezes. Cave is important because it contains late Pleistocene deposits (Goede, 1976b).

Cave JF155 is about $4 \mathrm{~km}$ north of Beginner's Luck and is sizeable, with steep pitches and a very high chamber (Fig. 9), quite different to the Breccia Ridge Cave description.

Fourthly, the label on the bag of bones that Turney et al. (2008: Table S4) took the sediment dating sample from read, 'small shelter on breccia ridge, Settlement Rd, Florentine Valley 21 XI 1976' suggesting that the OSL date came from this location.

Although sediment was dated from the bone collection it is unclear how the date relates to any of the bones since, when Breccia 


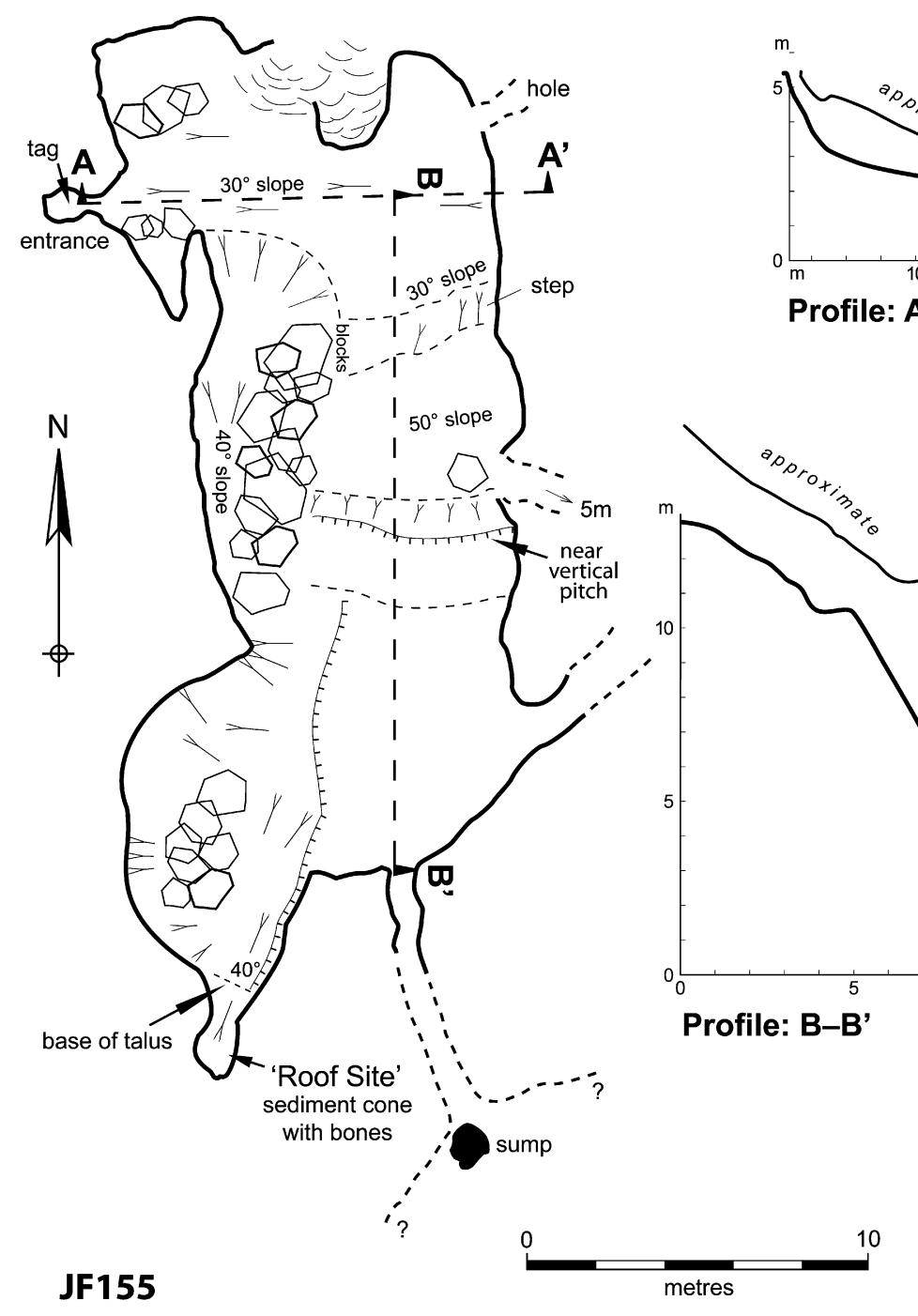

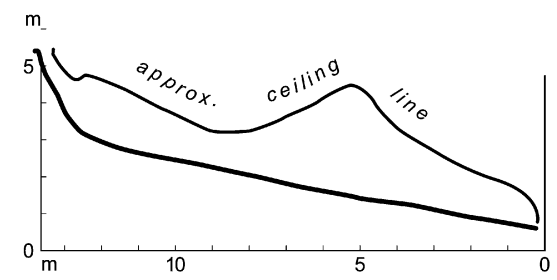

Profile: A-A'

J5s

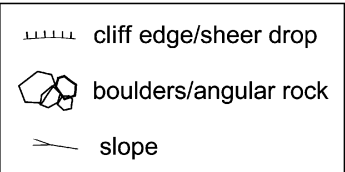

Surveyed: R. Cosgrove, S. Benjamin 18/02/07

Fig. 9. Plan and cross-section of un-named cave JF155. Simosthenurus sp. femur and associated large rib and pelvis were collected from the 'Roof Site'.

Ridge Cave was revisited in 1976, the trip report does not describe the exact locations of the bones and sediment samples (Goede, 1976a: 5-6). Max Jeffries and Therese Goede first collected bones from an unspecified location inside Breccia Ridge Cave (JF109) on October 1975. Another expedition to this cave in 1976 included Albert Goede, Peter Murray and Max Jeffries. Several bones were dug from cave fill and the party also collected bones from the floor of a medium sized chamber inside JF109. A leg bone of an extinct kangaroo was collected from a separate, small horizontal cave at the base of Breccia Ridge hill. Peter Murray also recovered a large tooth from indurated cave breccia in another separate location also exposed in the side of the hill (Goede, 1976a:6). It is thus unclear as to what locality the description on the bag of remains refers to. The lack of any stratigraphic context for the dated sediment sample makes it impossible to relate it to any of the bones.
Therefore the OSL age of $103 \pm 9 \mathrm{ka}$ on sediment reported by Turney et al. (2008) is not associated with the ESR date of $97 \mathrm{ka}$ or the AAR date of $30 \mathrm{ka}$ obtained from non-megafaunal bone in JF155 (Goede and Bada, 1985). Like the Scotchtown Cave, there is no information on the stratigraphic relationship between the OSL age and the extinct species listed in the Turney et al. (2008) Table S4 from Breccia Ridge Cave (JF109) or the other small caves. In any case the age is far in excess of initial human colonisation of Tasmania.

\subsection{Mt Cripps}

OSL dates from un-provenanced sediments trapped either inside bones or adhering to their surface only provide a minimum age for the last time these sediments were exposed to light, and do not date the bone itself. Although the method is an excellent one for

Table 5

Lawrence Livermore AMS collagen ages for Simosthenurus rib, femur and occipital bone from JF155 and JF154 respectively.

\begin{tabular}{|c|c|c|c|c|c|c|c|c|c|c|c|}
\hline Site & ACRF & Sample ID & Sample wt (mg) & $\delta^{13} \mathrm{C}$ & $\delta^{15} \mathrm{~N}$ & wt \% C & wt\% N & $\mathrm{C} / \mathrm{N}$ ratio & Atomic $\mathrm{C} / \mathrm{N}$ & Collagen yield (wt\%) & 14C Age BP (Sigma) \\
\hline JF155 & 2072 & JF155/Roof & 0.794 & -21.6 & 2.4 & 41.4 & 14.7 & 2.8 & 3.3 & 4.2 & $44,700 \pm 3300$ \\
\hline JF155 & 2073 & JF155/2 & 1.259 & -21.2 & 1.9 & 35.0 & 12.7 & 2.7 & 3.2 & 8.2 & $>46,200$ \\
\hline JF154 & 2074 & JF154/1 & 1.114 & -22.6 & 2.3 & 38.5 & 13.8 & 2.8 & 3.2 & 5.2 & $>45,400$ \\
\hline
\end{tabular}


dating beach, dune, shallow lake and shelter cave sediments, this is not true in deep caves where sediments and bones may be reworked by mass movement and fluvial processes in total darkness. This was quite clearly evident in our surveys of sites JF168 (Ultimate Cave), JF160, JF155, JF154 and JF97 (Titans Shelter) in the Florentine River valley where bones were grouped together on the cave floor associated with various sediment types. This problem would apply to the kind of deposits that are found at Site G in Titans Shelter and Site M in Beginners Luck Cave where reworking of both bone and sediments by running water has very likely occurred under conditions of either very low light intensity or total darkness.

The level of possible disturbance to the Mt Cripps sediments is unknown. We note that Turney et al. (2008) analysed 900 quartz grains for OSL dating from the nasal cavity of the Mt Cripps $P$. anak specimen, but only 69 were measured. Five were "omitted for clarity of presentation" (p2, Turney et al., Supplementary Information) from this group, leaving 64 grains for the final age determination. Samples $\mathrm{k} 2$ and $\mathrm{k} 3$ returned ages of $13.2 \pm 1.4 \mathrm{BP}(\mathrm{n}=15$ grains) (increased to $30 \pm 3 \mathrm{BP})$ and $36 \pm 3 \mathrm{BP}(\mathrm{n}=49$ grains) respectively from these 64 grains. OSL dates with this pattern commonly indicate bioturbation (Fillios et al., 2010), and this may have occurred to the Mt Cripps sediments in the ways discussed above.

\subsection{Summary}

The ages reported by Turney et al. (2008, Table 1) for fauna found in the Scotchtown Cave, Mowbray Swamp, Pulbeena Swamp and JF109 are unlikely to represent a suite of late-surviving megafauna as there is no evidence that any of the megafauna survived beyond $50 \mathrm{ka}$. If we eliminate all but $P$. anak, where the Tasmanian subadult is c. $60 \mathrm{~kg}$ (Turney et al., 2008: 12152) then it appears to be the sole survivor of a progressive extinction process of browsing mammals in Tasmania predating human arrival (Wroe and Field, 2006).

Reliance on the ambiguous chronologies from the Scotchtown Cave, Mowbray Swamp, Pulbeena Swamp and JF109 to support claims of megafaunal survival until human arrival is unwarranted.

\section{Evidence of human and palaeoecological impact}

We now turn to the third part of the paper. The results of megafauna and initial human settlement chronologies are presented in Fig. 10. All calibrations were made using the on-line CalPal program (Danzeglocke et al., 2010). They are given as age ranges as they better express the statistical likelihood of human-megafauna temporal overlap.

Turney et al. (2008) underpin their argument for a human cause of megafauna extinction by appealing to the fact that the Bassian Landbridge was open at c. 43,000 years ago and people crossed it immediately and dispatched the megafauna. As stated the oldest presently recorded human sites in Tasmania are Warreen Cave dated to $39,906 \pm 879$ calBP and Parmerpar Meethaner dated to $39,310 \pm 1151$ calBP where the lowest stone artefacts and bones are found. Redating by ABOX S-C method of the lowest cultural level at Warreen Cave returned an age of $33,170 \pm 670$ $(37,905 \pm 1229$ calBP; ANU-11710/143B, Keith Fifield, personal communication), well within the older AMS dates.

In Parmerpar Meethaner, sterile deposits $8 \mathrm{~cm}$ below the very rich cultural layers are dated to $43,792 \pm 842$ calBP (Cosgrove, 1995a), critically at the alleged entry date for people cited by Turney et al. (2008). However, humans make their first appearance here at $39,310 \pm 1151$ calBP and $37,785 \pm 852$ calBP. The Mount Cripps site (Fig. 1) is only $25 \mathrm{~km}$ northwest of Parmerpar Meethaner but the latter site contains no megafauna. Importantly, like Warreen Cave that also dates to this period, only extant prey species are known. In the earliest layer of Warreen Cave in Stratigraphic Unit $7(39,906 \pm 879$ calBP), the human prey animals are extant macropod, wombat and possum and make up 14.6\% $(n=211)$ of the total (Table 6). The other bones are of rodents, birds and small carnivorous marsupials. Cultural material diminished a few centimetres below where the oldest $14 \mathrm{C}$ sample was assayed, and the excavation was probably approaching sterile deposits, when finally further excavation was blocked by rocks (Allen, 1996).

Another date of $>42,000 \mathrm{BP}$ (Beta-61606) in sterile layers that underlie archaeological deposits at the Parawee chert quarry in northwestern Tasmania support the notion that Tasmania was not occupied by people at this time.

Johnson (2006 97) has speculated that the power of the Tasmanian archaeological evidence 'to detect human-megafauna overlap may be very low if megafauna species went extinct within a few thousand years of human arrival'. Although this is possible, at present there is no evidence to support human settlement before 40,000 calBP and, only one species, $P$. anak, is chronologically close to this time. Importantly, we can detect human overlap with the large $M$. giganteus titan but there's nothing to suggest that they were ever hunted (Fig. 10).

Although the eastern grey kangaroo, $M$. giganteus giganteus and their larger Pleistocene version, M. giganteus titan are present in the Florentine River valley's late Pleistocene pit fall fauna, only four bones of M. giganteus giganteus from over 2000 have been recorded from cultural levels at Nunamira Cave (Cosgrove, 1995b: 70). The overwhelming human prey animal is the smaller Bennett's wallaby (M. rufogriseus) (Cosgrove and Allen, 2001). Likewise, only two $M$. giganteus giganteus bones have been recovered from the c. 250,000 bones in the Kutikina Cave assemblage in western Tasmania (Garvey, 2007).

Historic hunting of $M$. giganteus giganteus observed by G.A. Robinson in eastern Tasmania in the 1820s (Barker and Caughley, 1990; Plomley, 1966) and the data from ice age sites in western Tasmania together with the pre-European distribution of $M$. gigantues giganteus shows that this animal avoided dense scrub and is absent from western Tasmania today (Hocking and Guiler, 1983). Since some of the late Pleistocene cave sites are situated outside the ecological range of this large kangaroo, where patches of grassland surrounded by infertile scrub restricted the distribution of these animals (Cosgrove, 1995b: 96-101), it is unsurprising that they are rarely detected in the western archaeological sites. They have a low tolerance for scrub, browse and infertile landscapes as shown by the limited historical distribution of these animals (Barker and Caughley, 1990). M. gigantues giganteus are selective feeders (Johnson, 1985: 8; Strahan, 1983: 244) when compared to Bennett's wallaby (M. rufogrieus) that are described as,

... intermediate feeders between the purely browsing and grazing macropods such as the swamp wallaby and eastern grey kangaroo respectively (Johnson, 1985: 8).

Compared to the eastern grey kangaroo, M. rufogriseus, has a wide distribution (Johnson, 1985: 7), from the highest alpine zones $>1200 \mathrm{~m}$ to coastal plains (Driessen, 1988:5; Gibson and Kirkpatrick, 1985) and are absent from areas with less than $400 \mathrm{~mm}$ of rainfall (Johnson, 1985: 7). This species seems resilient in the face of climatic perturbations and human hunting, clearly surviving the height of the last glacial maximum as an important human prey (Cosgrove, 1995b: 101-103).

Although this explains the low numbers of M. giganteus giganteus in western Tasmania and possibly P. anak, it does not explain the lack of representation in sites in the drier north and east. No bones of $M$. giganteus giganteus are recorded in late Pleistocene levels of ORS 7 and Parmerpar Meethaner despite both being within the ecological range of this animal (Cosgrove, 1995b: 85, 1995a). The lack of any 


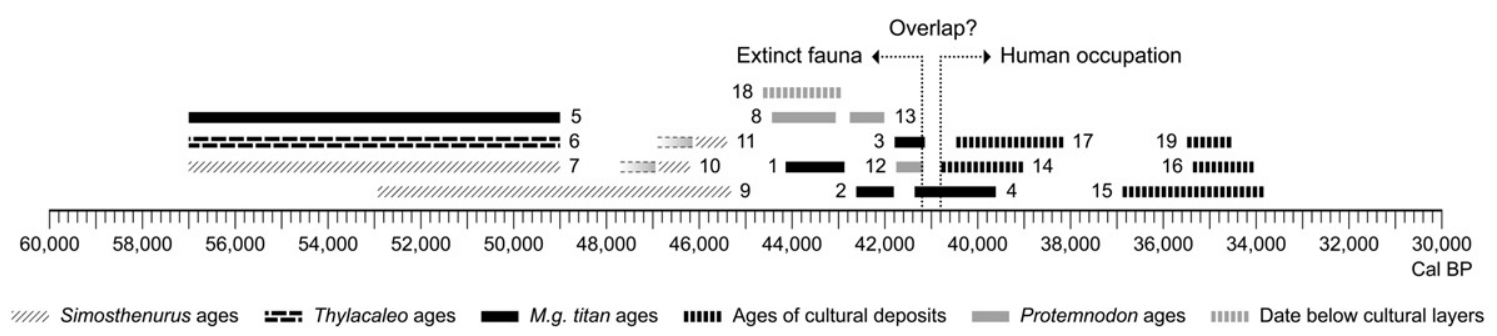

\begin{tabular}{|c|c|c|c|c|c|c|c|c|}
\hline Code & $\begin{array}{l}\text { Palaeoentological Sites I } \\
\text { Oldest Human Sites }\end{array}$ & Species & $\begin{array}{l}\text { Material } \\
\text { Dated }\end{array}$ & $\begin{array}{c}{ }^{14} \mathrm{C} /{ }^{*} \mathrm{ESR} \\
\text { Dates }\end{array}$ & $\begin{array}{l}\text { CalPal-Online } \\
\text { Calibrated BP }\end{array}$ & $\begin{array}{l}\text { CalPal-Online } \\
\text { Age Range } 68 \%\end{array}$ & $\begin{array}{l}\text { ESR Age Range } \\
68 \% \pm 1 \text { Sigma }\end{array}$ & References \\
\hline 1 & Ultimate Cave & M. giganteus titan & Collagen & $39,530 \pm 580$ & $43,506 \pm 635$ & $42,871-44,141$ & & This paper \\
\hline 2 & Titan's Shelter square F & M. giganteus titan & Collagen & $37,650 \pm 470$ & $42,214 \pm 404$ & $41,809-42,618$ & & This paper \\
\hline 3 & Titan's Shelter square F & M. giganteus titan & Collagen & $36,210 \pm 390$ & $41,466 \pm 325$ & $41,141-41,791$ & & This paper \\
\hline 4 & Titan's Shelter square F & M. giganteus titan & Collagen & $35,610 \pm 360$ & $40,486 \pm 874$ & $39,612-41,360$ & & This paper \\
\hline 5 & Titan's Shelter square G & M. giganteus titan & Enamel & * $53,000 \pm 4000$ & - & - & $49,000-57,000$ & This paper \\
\hline 6 & Titan's Shelter square G & Thylacaleo carnifex & - & $\star 53,000 \pm 4000$ & - & - & $49,000-57,000$ & This paper \\
\hline 7 & Titan's Shelter square G & Simosthenurus & - & $* 53,000 \pm 4000$ & - & - & $49,000-57,000$ & This paper \\
\hline 8 & Titan's Shelter square G & Protemnodon anak & Collagen & $39,980 \pm 610$ & $43,748 \pm 688$ & $43,060-44,436$ & & Turney et al. 2008 \\
\hline 10 & JF155 & Simosthenurus & Collagen & $>46,200$ & - & - & & This paper \\
\hline 11 & JF154 & Simosthenurus & Collagen & $>45,400$ & - & - & & This paper \\
\hline 12 & Mt Crips & Protemnodon anak & Collagen & $36,200 \pm 300$ & $41,465 \pm 292$ & $41,173-41,757$ & & Turney et al. 2008 \\
\hline 13 & Mt Crips & Protemnodon anak & Collagen & $37,920 \pm 340$ & $42,386 \pm 370$ & $42,015-42,756$ & & Turney et al. 2008 \\
\hline 14 & Warreen Cave & Wood (AMS) & Charcoal & $34,790 \pm 510$ & $39,906 \pm 879$ & $39,026-40,785$ & & Allen 1996 \\
\hline 15 & Nunamira Cave & Wood & Charcoal & $30,750 \pm 1340$ & $35,360 \pm 1518$ & $33,842-36,878$ & & Cosgrove 1989 \\
\hline 16 & Nunamira Cave & Wood & Charcoal & $30,420 \pm 690$ & $34,710 \pm 652$ & $34,058-35,362$ & & Cosgrove 1989 \\
\hline 17 & Parmerpar Meethaner & Wood (AMS) & Charcoal & $33,850 \pm 450$ & $39,310 \pm 1151$ & $38,159-40,461$ & & Cosgrove $1995 a$ \\
\hline 18 & Parmerpar Meethaner & Wood (AMS) & Charcoal & $39,970 \pm 950$ & $43,792 \pm 842$ & $42,952-44,627$ & & Cosgrove 1995a \\
\hline
\end{tabular}

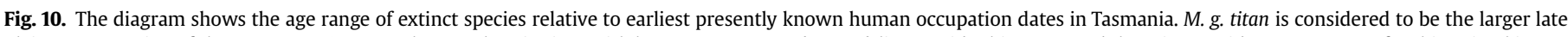

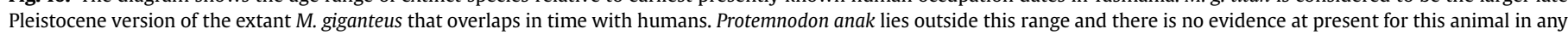
of the archaeological sites. Calibrated ages and their range are based on the CaPal on-line program (Danzeglocke et al., 2010).

large fauna over $30 \mathrm{~kg}$ from late Pleistocene Tasmanian human sites is surprising, suggesting a complex interaction between hunters and their prey. This is discussed further below.

Turney et al. (2008) dismiss a role for climate in causing P. anak extinction. This is based on a pollen core from Lake Selina in far western Tasmania claimed to be representative of palaeoecological changes in southern midlatitudes. In fact, it does not serve this function very well as its position in mountainous terrain close to the west coast and the prevailing rain laden winds generally buffers it from any extreme climatic events in the east and north. Today it receives an average annual rainfall of at least $3500 \mathrm{~mm}$ (Bureau of Meteorology, 2008: 29). To the east the drier Midlands Valley receives only 500-600 mm, while the Florentine River valley receives

\section{Table 6}

Warreen Cave faunal frequency and proportion from square $A$ in the first 4000 years of occupation. Prey animals (in bold) make up $14.56 \%$ of Stratigraphic 7 . Small mammals and marsupials make up the remainder.

\begin{tabular}{lcc}
\hline Species & Frequency & Percentage \\
\hline Antechinus sp. & 7 & 0.767 \\
Bird & 10 & 1.095 \\
Cercartetus nanus & 8 & 0.876 \\
Dasyurus viverrinus & 34 & 3.724 \\
Large macropod & $\mathbf{8}$ & $\mathbf{0 . 8 7 6}$ \\
Large mammal & $\mathbf{2 2}$ & $\mathbf{2 . 4 1}$ \\
Macropus rufogriseus & $\mathbf{2 7}$ & $\mathbf{2 . 9 5 7}$ \\
Mastacomys fuscus & 64 & 7.01 \\
Medium mammal & $\mathbf{5 5}$ & $\mathbf{6 . 0 2 4}$ \\
Pseudocheirus peregrinus & $\mathbf{2}$ & $\mathbf{0 . 2 1 9}$ \\
Rodent & 187 & 20.482 \\
Small macropod & $\mathbf{5}$ & $\mathbf{0 . 5 4 8}$ \\
Small mammal & 460 & 50.383 \\
Unidentified taxon & 10 & 1.095 \\
Vombatus ursinus & $\mathbf{1 5}$ & $\mathbf{1 . 5 3 4}$ \\
Total & 913 & 100.00 \\
\hline
\end{tabular}

an average annual rainfall of $1272 \mathrm{~mm}$. During the late Pleistocene, these levels would have been reduced further by up to $45-50 \%$ indicated by the increase in herbs, small trees and subalpine species (Colhoun, 2000; Kirkpatrick, 1986). Kirkpatrick and Folwer's modelling of late Pleistocene vegetation shows that in addition to the alpine herbs in the west, grass and grassy woodland was distributed in the southeast, Midlands and north (Kirkpatrick and Folwer, 1998). While Lake Selina has one of the best long chronologies, the resolution is too low to identify the magnitude and frequency of short-term climatic shifts of less than 2000 years, which are important scales for understanding faunal responses. Nor is it sensitive enough to indicate the entire range of vegetation mosaics during this time. Thus the Lake Selina record is unlikely to be representative of small-scale climate and vegetation change for the whole of Tasmania.

Critically the time close to the assumed human overlap with $P$. anak in Tasmania coincides with the Lake Mungo Geomagnetic Excursion. Bowler et al. (2003) observes that "A most significant climatic change of the last $60 \mathrm{kyr}$ occurred near $40 \mathrm{kyr}$ when early lake shore Homo sapiens....were forced to adapt to increasing aridity". How far this impacted on populations of Tasmanian P. anak is unknown at present but sudden climatic shifts towards aridity may have increased pressure on their demographic resilience (Wroe and Field, 2006). It may be that at these higher latitudes the impact on population levels may have been greater.

The influence of climate change in the region is demonstrated on smaller species such as the extinct Eastern Hare wallaby (Lagorchestes leporides) and Rufus Bettong (Aepyprymnus rufescens). They continued to co-exist with humans in the Bass Plain region at least until 18,000 BP (Brown, 1993). Both require grassed open forest and access to tussocks under which they build grass-lined nests and, the climate at this time would have suited these animals. The Toolache wallaby (Macropus greyi) also now extinct was present in northwest Tasmania (Horton and Murray, 1980) dated to 
between $22,750 \pm 420$ and $14,850 \pm 190 \mathrm{BP}$ at Cave Bay Cave on Hunter Island and $22,130 \pm 180 \mathrm{BP}$ at Pulbeena Swamp. It's suggested that they were open country species avoiding thick forest and scrub (Finlayson, 1927). But they too, become extinct after this time presumably due to increasing forest cover associated with changes in climate.

\section{Discussion}

We have argued elsewhere that the dominance of Bennett's wallaby (M. rufogriseus) in the archaeological sites over all other animals can be explained by Aboriginal prey choice and patch selection (Cosgrove and Allen, 2001). The theory posits that where highly ranked prey species are available, they will be chosen above all others as economically attractive. The focus of Aboriginal hunting on Bennett's wallaby and wombat to the exclusion of other species explains the present archaeological patterns (Cosgrove et al., 1990; Cosgrove and Allen, 2001). The over-representation of macropod long bones in the Tasmanian sites is argued to be a function of intensive marrow extraction in high latitude glacial climates to compensate for a lean meat diet and low amounts of dietary carbohydrates (Cosgrove, 1995b: 105-106, 1999; Cosgrove and Allen, 2001: 412; Pike-Tay et al., 2008). M. giganteus titan, $M$. giganteus giganteus, $P$. anak and other megafauna would be very attractive targets as their bones have much bigger marrow cavities containing fats and proteins (Garvey, 2010).

Importantly the Tasmanian emu (Dromaius diemenensis) is also very rare in the archaeological record although their eggshell is persistent $(n=333)$ in Nunamira Cave suggesting selective exploitation of the eggs of this species at $28,000 \pm 720 \mathrm{BP}$ $(32,659 \pm 648$ calBP $)$ and after $16,120 \pm 180(19,282 \pm 305$ calBP $)$ (Cosgrove, 1995b: 76-77).

The obvious question is, why is there little or no archaeological evidence of exploitation of either large extinct and/or extant animals? We present several possibilities.

Firstly the sites are not representative of late Pleistocene human occupation and the lack of evidence is more to do with sampling (Johnson, 2006). This is possible but as argued elsewhere, is not convincing (Wroe and Field, 2006: 2695). Given their attractiveness as human prey, the likelihood of a minimum encounter and capture every thousand years or so, and the demonstrated overlap with humans of $M$. giganteus giganteus and $M$. giganteus titan, the expectation would be that the remains of some large animals might be preserved in the deposits. It is possible that $M$. giganteus titan and $P$. anak bones are contained within the caves and remain undiscovered. Our large sample of bones from sites across a range of environments and their absence from the 40,000 calBP levels of Warreen Cave and Parmerpar Meethaner seems sufficient to discard this notion at present.

Secondly this expectation is wrong and that the Aborigines did not take these animals on encounter. This possibility cannot be totally discounted but hunters have taken prey animals in this size range everywhere in the world over the last 100,000 years or more (e.g. Burke, 2004; Byers and Hill, 2009; Byers and Ugan, 2005; Gaudzinski et al., 1996; Winterhalder and Lu, 1997). Indeed, the ethnohistorical records of Tasmania describe Aborigines encountering and occasionally killing both emu (D. diemenensis) and $M$. giganteus giganteus during their daily movements (Plomley, 1966: 214, 487, 490; Ross, 1830). If, as likely, animals of this size would have been attractive late Pleistocene human prey, then the total absence of $M$. giganteus titan and $P$. anak from archaeological sites within their ecological range again indicates a relatively low population and/or prior extinction of the latter.

Thirdly, broad temporal and spatial overlap notwithstanding, people in this time period rarely if ever encountered $M$. giganteus titan and other extinct species, because human populations were very small. Evidence for reduced artefact discard rates from the earliest levels of the oldest sites suggests relatively low numbers of people on the landscape (Cosgrove, 1995a). Webb also considers that initial Sahul human populations were too small to have a significant impact on megafauna (Webb, 2008). This is also borne out by the much lower erosional rates recorded in Tasmania between $45,000-40,000 \mathrm{BP}$. After this time, particularly at 35,000 BP they increase dramatically, argued to be a product of increased human disturbance that coincides with archaeological evidence for first human arrivals (McIntosh et al., 2009). The indications are that human populations were initially low and the potential for human impact on $P$. anak was therefore probably very limited.

It is not possible to reconstruct the community ecology of large mammals during this period for the reasons outlined in Cosgrove and Allen (2001: 398). Nevertheless, if conditions were as open and conducive as the fossil and pollen record indicate for large grazing macropods, (Colhoun, 2000; Kirkpatrick and Folwer, 1998; Macphail, 1975, 1979) we could expect reasonable numbers on the landscape based on modern analogues of $M$. giganteus giganteus distribution patterns and populations numbers (Barker and Caughley, 1990; Tanner and Hocking, 2001).

There is also good evidence for the seasonal movement of people in winter to lower elevations and to higher altitudes in summer (Pike-Tay et al., 2008). Whether the seasonal movement of humans coincided with similar movements of M. giganteus titan and $P$. anak is difficult to assess. Again based on modern representatives of $M$. giganteus giganteus, these animals are relatively gregarious and have home ranges of up 20-27 hectares (Dawson, 1995: 37) with greater movements in summer of between 1 and $3 \mathrm{~km}$ (Clarke et al., 1989: 614). Jarman and Southwell (1986: 402, 424) also found small seasonal movements by grey kangaroos in their two-year study at Wallaby Creek, with highest concentrations of animals along the drainage lines. The undulating and open Florentine River valley could easily accommodate concentrations of megafauna within its area of c. $200 \mathrm{~km}^{2}$. It is likely therefore that hunters venturing into the Florentine, the Ouse and Forth River valleys in the summer could have encountered megafauna and large macropods such as $M$. giganteus titan.

If $P$. anak and Aborigines did overlap and these animals were taken on encounter, then there maybe a number of reasons for their archaeological absence.

Firstly the bones didn't make it back to sites because of transport considerations. This is possible but people would have had to be so diligent about not carting any large bones back to cave sites as to be fastidious in the extreme. The Tasmanian $P$. anak was over $60 \mathrm{~kg}$ (Turney et al., 2008) and butchery studies of animals in this size range show that body parts were routinely transported back to campsites (Marean and Cleghorn, 2003; Metcalfe and Barlow, 1992; O'Connell et al., 1990; O'Connell and Hawkes, 1988).

Secondly they weren't preserved as well as other faunal remains (Roberts and Jacobs, 2008). This is unlikely as the bone preservation in the limestone caves of even the tiniest marsupial mouse scapula in the 35,000-year old layers is excellent. In addition, megafauna bones are much larger, more robust and denser than the two major prey species, Macropus rufogriseus and V. ursinus (Cosgrove and Allen, 2001; Garvey, 2010).

Thirdly the sites sampled were used primarily if not exclusively in connection with specialised wallaby hunts and/or used for specialised open-air kill sites. This remains a possibility although, as mentioned above, sites in a range of different late Pleistocene environments attractive to large grazing and browsing animals have been excavated without any evidence of megafauna (Bowdler, 1984; Kiernan et al., 1983; Brown, 1993; Allen, 1996; Sim, 1998; Cosgrove, 1995a; Cosgrove, 1989). 


\section{Conclusion}

The results show three important patterns of late Pleistocene human prey choice.

a) If there were some human overlap with $P$. anak at 41 ka we cannot find any convincing archaeological evidence for this (contra Turney et al., 2008),

b) The dates demonstrate a human overlap with M. giganteus titan and the later M. giganateus giganteus. These were apparently overlooked by human hunters in favour of the more abundant and predictable Bennett's wallaby (M. rufogriseus) and wombat (V. ursinus),

c) Although P. anak was an attractive human prey, its absence in archaeological record is either because their populations were quite low, encountered so infrequently that they don't show up, or had already become extinct by the time humans arrived.

Based on our recent evidence we find no support for the overkill hypothesis as framed by Roberts et al. (2001), Turney et al. (2008) and Roberts and Jacobs (2008) for Tasmania.

\section{Acknowledgements}

The Australian Institute of Nuclear Science and Engineering (AINSE award number 01/037P), La Trobe University Research Enhancement Fund and the Department of Anthropology, University of Utah generously funded this project. We thank the Tasmanian Museum and Art Gallery (TMAG), Queen Victoria Museum, Tasmanian Aboriginal Lands and Sea Council and Tony Brown, Curator of Indigenous Cultures (TMAG) for allowing us to use the bone material for the dating program. Craig Reid (Queen Victoria Museum) provided valuable information about the history and images of the Scotchtown cave. We thank Arthur Clarke, Serena Benjamin, Matt Cracknel and Ian Houshold for their valuable assistance and caving expertise. Dale Owen, Anthony Dall'Oste, Marnie Kibble, Peter Saad, and Justine Ackroyd also assisted greatly with our caving surveys and for this we thank them. Forestry Tasmania and the Forestry Geeveston Office gave their permission to work in the Florentine River valley. Eric Stadler is thanked for his hospitality and help during fieldwork. John Richardson provided photographs and measurements of the Simosthenurus sp. long bones and cranium and for this we are very grateful. Gavin Prideaux identified the Simosthenurus skull and femur. We thank R.G. Roberts and Z. Jacobs, University of Wollongong, for lending us their calibrated gamma spectrometer on short notice. Rudy Frank and Wei Ming drew the maps, figures and also assisted with fieldwork. We thank Jim Allen, Fran Cosgrove, Gavin Prideaux and two other referees who provided useful comments and suggestions on how to improve the paper.

\section{Appendix A. ANSIE: chemistry report on the AMS dates of large macropod bones}

\begin{tabular}{ll} 
Client & Dr Richard Cosgrove \\
Sample codes & \\
Lab Code & Client Code \\
OZI213 & MT IV JF97F \\
OZI214 & MT IV Macropus titan - Titan's shelter F2 \\
OZI215 & MT IV Macropus titan - Titan's shelter G2 \\
\hline
\end{tabular}

Samples OZI213-OZI215 were pre-treated at the Oxford Radiocarbon Accelerator Unit (ORAU), collagen that was extracted from samples OZI213 and OZI214 at the ORAU showed sufficient preservation and effective removal of contamination to achieve reliable radiocarbon results. An initial test of Sample OZI215 showed it to be degraded and attempts at collagen extraction were not successful. The collagen that was obtained from OZI213 and OZI214 was then processed to graphite and measured at the ANSTO.

\section{Pre-treatment method}

The ORAU uses the ultrafiltration protocol (Higham et al., 2006; Bronk Ramsey et al., 2004; Brown et al., 1988) to pretreat bone samples for radiocarbon dating. The ultrafiltration method has been shown to remove carbonaceous contamination more effectively than other methods (Bronk Ramsey et al., 2004; Higham et al., 2006).

The main steps in the ultrafiltration protocol are:

1. The bone sample is cleaned with an airbrasive system and then crushed.

2. The crushed bone samples are demineralised with $0.5 \mathrm{M} \mathrm{HCl}$.

3. Humics are removed with $0.1 \mathrm{M} \mathrm{NaOH}$.

4. Dissolved $\mathrm{CO}_{2}$ is removed with $0.5 \mathrm{M} \mathrm{HCl}$.

5. Samples are gelatinised with $\mathrm{pH} 3$ ultrapure water (heated to $75^{\circ} \mathrm{C}$ for $20 \mathrm{~h}$ ).

6. Samples are filtered through $100 \mu \mathrm{m}$ polyethylene eezi-filters ${ }^{\mathrm{TM}}$ to remove insoluble residues.

7. Eezi-filtered gelatin is then transferred to pre-cleaned Millipore $30 \mathrm{kD}$ ultrafilters and centrifuged until sufficiently filtered.

8 . The $>30 \mathrm{kD}$ solution is then freeze dried.

The main enhancement of this pre-treatment method is the ultrafiltration step. Ultrafiltration acts to remove material with a molecular weight below $30 \mathrm{kD}$. By eliminating the particles with a molecular weight below $30 \mathrm{kD}$ contaminants such as salts, fulvic acids and degraded collagen are removed. Fragments of undegraded collagen are retained by the $30 \mathrm{kD}$ filter. The ORAU has shown that ultrafiltration enhances the quality of the extracted collagen and improves the reliability of the age that is obtained (Higham et al., 2006).

Some problems have been encountered with the ultrafiltration method in the past and have been fully explored in Bronk Ramsey et al. (2004). More specifically contamination was arising from the use of the ultrafilters that were used at the ORAU. This contamination originates from the glycerol which is added to the ultrafilter membrane during production. The ultrafiltration step in this method only adds carbonaceous contamination to the samples if the filters are not sufficiently cleaned. The laboratories at the ORAU discovered that a vigorous cleaning procedure, excess to the manufacturer's suggestions, was required when using the ultrafilters for the purification of gelatin from bones.

Since the problems with the ultrafiltration protocol have been discovered the new cleaning protocol coupled with quality assurance measures have become routine at the ORAU and there is confidence that the use of ultrafilters does not pose a contamination risk for samples.

The collagen that was obtained from OZI213 and OZI214 was then processed to graphite at the ANSTO laboratories as per Hua et al. (2001). The radiocarbon dates that resulted are detailed below.

\section{Results}

\section{Preservation of collagen}

Chemical indicators confirmed that the collagen that was extracted from samples OZI213 and OZI214 was preserved sufficiently for dating (quality tests are explained below). Sample OZI215 was too degraded to process (Table A1). 
Table A1

${ }^{14} \mathrm{C}$ Determinations of Samples OZI213-OZI215.

\begin{tabular}{|c|c|c|c|c|c|c|c|c|c|c|c|c|}
\hline \multirow[t]{2}{*}{ Sample } & \multirow[t]{2}{*}{ Client ID } & \multirow[t]{2}{*}{$\begin{array}{l}\text { Whole bone } \\
\mathrm{N}(\%)\end{array}$} & \multirow[t]{2}{*}{$\begin{array}{l}\text { Collagen } \\
\text { yield (\%) }\end{array}$} & \multirow[t]{2}{*}{ Collagen $13 \mathrm{C}$} & \multirow[t]{2}{*}{ Collagen C:N } & \multirow[t]{2}{*}{$\begin{array}{l}\delta(13 C) \text { per mil } \\
\text { (Graphite) }\end{array}$} & \multicolumn{2}{|c|}{$\begin{array}{l}\text { Percent modern } \\
\text { carbon (ANSTO) }\end{array}$} & \multicolumn{2}{|c|}{$\begin{array}{l}\text { Conventional C14 } \\
\text { age (ANSTO) }\end{array}$} & \multicolumn{2}{|c|}{ LLNL results } \\
\hline & & & & & & & $\mathrm{pMC}$ & $1 \sigma$ error & Yrs BP & $1 \sigma$ error & Yrs BP & $1 \sigma$ error \\
\hline OZI213 & MT IV JF97F & 1.52 & 3.77 & -22.2 & 3.24 & -21.70 & 1.41 & 0.08 & 34,230 & 460 & 35,610 & 360 \\
\hline OZI214 & $\begin{array}{l}\text { MT IV Macropus } \\
\text { Titan's shelter F2 }\end{array}$ & 4.2 & 1.73 & -21.1 & 3.22 & -21.00 & 1.28 & 0.09 & 35,000 & 620 & 37,650 & 470 \\
\hline OZI215 & $\begin{array}{l}\text { MT IV Macropus } \\
\text { Titan's shelter G2 }\end{array}$ & None detected & \multicolumn{10}{|c|}{ Too degraded to process. No collagen resulting after pre-treatment } \\
\hline
\end{tabular}

Samples OZ213 and OZ214 exhibited an acceptable level of nitrogen in the whole bone sample. Measuring the N\% of the whole bone allows us to estimate the quantity of collagen present before chemical treatment commences. The quantity of nitrogen usually ranges from approximately $4 \%$ in a fresh bone to below $0.2 \%$ in a poorly preserved bone (Tisnérat-Laborde et al., 2003). Sample OZI215 did not contain sufficient nitrogen to give a measurement on the stable isotope mass spectrometer.

The C: $\mathrm{N}$ ratios of the collagen were within the acceptable range indicating that the collagen preservation was acceptable for dating and contaminants had been effectively removed. At ANSTO C:N ratios between 2.9 and 3.5 are considered acceptable. These acceptable values are based on numerous studies (primarily DeNiro, 1985) that have investigate the use of C:N ratios as a tool to detect the contamination of collagen.

The collagen yields for both OZI213 and OZI214 indicated an acceptable level of preservation. Attempts were made to pretreat OZI215 but no collagen of acceptable quality could be extracted.

\section{Quality assurance tests for ultrafilters}

As explained earlier the effective removal of glycerol from the ultrafilters is imperative to ensure that radiocarbon dates have not been affected by using these filters. A number of tests are performed to make sure all carbonaceous contamination has been removed. The quality assurance tests include:

Measuring the quantity of carbon that is remaining on the ultrafilters after they have been cleaned. To achieve this a ultrafilter is selected (randomly) and a sample is taken from the top of the filter for carbon content analysis. The test sample that was measured with samples OZI213 and OZI214 exhibited no measurable carbon indicating that the ultrafilters had been cleaned satisfactorily.

1. A set of standards with known ages are run alongside the samples with unknown ages. The old high mass standard that ran alongside the samples yielded an age of $>50,000 \mathrm{yrs} B P$, which demonstrates that no modern contamination resulted from the pre-treatment of the bone samples.

2. The glycerol that coats the ultrafilters is extracted and dated. The glycerol used on the batch of ultrafilters that was used in processing OZI213 and OZI214 resulted in a date of $1.06 \mathrm{pMC}$ (with an error of \pm 0.0034 ). Therefore if the samples were affected by contamination resulting from the ultrafilters you would expect older age offsets.

\section{Summary}

Chemical indicators showed that the collagen extracted from samples OZI213 and OZI214 was sufficiently preserved and carbon contamination had been effectively removed for reliable radiocarbon dates to be obtained. Quality assurance tests have confirmed that the use of ultrafilters during the pre-treatment of these samples did not affect the dates of these samples. Sample OZI215 was poorly preserved and collagen of acceptable quality could not be obtained.

\section{Appendix B. Report on the ESR dating}

Grün $(2006,2007,2008)$ has recently reviewed ESR dating. The dating procedures of the sample 2379 from Titan's Sheter, square G3, spit 5 followed those routinely applied in the ANU ESR dating laboratory. An enamel fragment with attached dentine was removed from the tooth and analysed for uranium and thorium using laser ablation ICP-MS (Eggins et al., 2003, 2005). Two laser ablation tracks across the enamel and dentine yielded concentration values of $0.13 \pm 0.01$ and $2.1 \pm 0.1 \mathrm{ppm} U$ for enamel and dentine, respectively. U-series isotopic ratios could only be measured in the dentine, yielding a ${ }^{234} U /{ }^{238} U$ activity ratio of $1.329 \pm 0.044$ and $\mathrm{a}^{230} \mathrm{Th} /{ }^{234} \mathrm{U}$ activity ratio of $0.295 \pm 0.065$. The U-series ratios correspond to respective apparent U-series ages of $37.5^{+10.2 /-9.4 \mathrm{ka}}$. These values were used for both dentine and enamel. For ESR dose analysis, the enamel was powdered and 2 aliquots (2379A and B) were successively irradiated in 16 steps to 932 Gy. Radiation doses were monitored with alanine dosimeters and evaluated against a calibrated dosimeter set (A. Wieser, Messtechnik, München). Dose values of $25.4 \pm 0.7$ and $23.2 \pm 0.4 \mathrm{~Gy}$ were obtained fitting the natural spectrum back into the irradiated ones (Grün, 2002).

For the assessment of the environmental dose rate, a sediment samples was collected in the immediate vicinity of the tooth and analysed by solution ICP-MS analysis, yielding $1.43 \pm 0.2 \mathrm{ppm} \mathrm{U}$, $5.69 \pm 0.2 \mathrm{ppm}$ Th and $0.96 \pm 0.05 \% \mathrm{~K}$. An in situ gamma spectrometric measurement yielded an environmental gamma dose rate of $295 \pm 16 \mu \mathrm{Gy} / \mathrm{a}$. The tooth was found at a depth of $10 \pm 2 \mathrm{~m}$ below the rock surface. This value was used for the calculation of the cosmic dose rate of $63 \pm 11 \mu \mathrm{Gy} / \mathrm{a}$ (Prescott and Hutton, 1994). Water concentrations were measured for three sediment samples, yielding $38 \pm 4 \%$ and in dentine it was assumed to be $10 \pm 5 \%$.

For the calculation of the internal dose rate values, beta attenuation values of Marsh (1999) and an alpha efficiency of $0.13 \pm 0.02$ (Grün and Katzenberger-Apel, 1994) were used. Combining the ESR and U-series data for the modelling of the U-uptake (Grün et al., $1988)$, US/ESR ages of $55 \pm 3 \mathrm{ka}(2379 \mathrm{~A})$ and $51 \pm 3 \mathrm{ka}(2379 \mathrm{~B})$ were obtained (with an associated p-value of $-0.58 \pm 0.41$ ). This results in a best estimate of $53 \pm 4 \mathrm{ka}$.

The calculations are critically dependent on the external dose values, which constitute more than $93 \%$ of the total dose rate. It was therefore of utmost importance that the external gamma dose rate was measured in situ. Any assumptions with respect to uranium uptake and disequilibrium have very small effects on the final age calculation $(<2 \%)$.

\section{References}

Allen, J. (Ed.), 1996, Report of the Southern Forests Archaeological Project, vol. 1. School of Archaeology, La Trobe University, Bundoora.

Banks, M.R., Colhoun, E.A., van den Geer, G., 1976. Late Quaternary Palorchestes azeal (Mammalia, Diprotodontidae) from northwestern Tasmania. Alcheringa 1 (2), 159-166. 
Barker, R.D., Caughley, G., 1990. Distribution and abundance of kangaroos (Marsupialia: Macropodidae) at the time of European contact: Tasmania. Australian Mammalogy 13, 157-166.

Barnosky, A.D., Koch, P.L., Feranec, R.S., Wing, S.L., Shabel, A.B., 2004. Assessing the causes of Late Pleistocene extinctions on the continents. Science 306, 70-75.

Bowdler, S., 1984. Hunter Hill, Hunter Island. Terra Australis 8. Department of Prehistory, Research School of Pacific Studies, Australian National University, Canberra.

Bowler, J.M., Johnston, H., Olley, J.M., Prescott, J.R., Roberts, R.G., Shawcross, W. Spooner, N., 2003. New ages for human occupation and climatic change at Lake Mungo, Australia. Nature 42, 837-840.

Bronk Ramsey, C., Higham, T., Bowles, A., Hedges, R., 2004. Improvements to the pretreatment of bone at Oxford. Radiocarbon 46 (1), 155-163.

Brown, S., 1993. Mannalargenna Cave: a Pleistocene site in Bass Strait. In: Smith, M., Spriggs, M., Fankhauser, B. (Eds.), Sahul in Review. Department of Prehistory, Research School of Pacific Studies, Australian National University, Canberra, pp. 258-271.

Brown, T.A., Nelson, D.E., Vogel, J.S., Southon, J.R., 1988. Improved collagen extraction by modified Longin method. Radiocarbon 30 (2), 171-177.

Burke, A., 2004. The ecology of Neanderthals: preface. International Journal of Osteoarchaeology 14, 155-161.

Bureau of Meteorology, 2008. Climate of Australia. Commonwealth of Australia, Canberra.

Byers, D.A., Hill, B.L., 2009. Holocene hunting strategies at Hogup Cave, Utah. American Antiquity 74 (2), 299-321.

Byers, D.A., Ugan, A., 2005. Should we expect large game specialization in the late Pleistocene? An optimal foraging perspective on early Paleoindian prey choice. Journal of Archaeological Science 32, 1624-1640.

Clarke, J.L., Jones, M.E., Jarman, P.J., 1989. A day in the life of a Kangaroo: activities and movements of Eastern Grey Kangaroos Macropus giganteus at Wallaby Creek. In: Grigg, G., Jarman, P., Hume, I. (Eds.), Kangaroos, Wallabies and Rat-Kangaroos. Surrey Beatty and Sons Pty Limited, New South Wales, Australia, pp. 611-618.

Colhoun, E.A., 1982. Stratigraphy, pollen analysis, and palaeoclimatic interpretation of Pulbeena Swamp, Northwestern Tasmania. Quaternary Research 18 (1),108-126.

Colhoun, E.A., 1986. Field problems of radiocarbon dating in Tasmania. Papers and Proceedings of the Royal Society of Tasmania 120,1-6.

Colhoun, E.A., 2000. Vegetation and climate change during the last interglacial-glacial cycle in western Tasmania, Australia. Palaeogeography, Palaeoclimatology, Palaeoecology 155, 195-209.

Cosgrove, R., 1989. Thirty thousand years of human colonization in Tasmania: new Pleistocene dates. Science 243, 1703-1705.

Cosgrove, R., 1995a. Late Pleistocene behavioural variation and time trends. Archaeology in Oceania 30, 83-104.

Cosgrove, R., 1995b. The illusion of riches: scale resolution and explanation in Tasmanian Pleistocene human behaviour. Tempus Reparatum, BAR International Series 608, Oxford.

Cosgrove, R., 1999. Forty-two degrees south: the archaeology of Late Pleistocene Tasmania. Journal of World Prehistory 13 (4), 357-402.

Cosgrove, R., Allen, J., 2001. Prey choice and Hunting Strategies in the Late Pleistocene: evidence from Southwest Tasmania. In: Anderson, A., O'Connor, S., Lilley, I. (Eds.), Histories of Old Ages: Essays in Honour of Rhys Jones. Coombs Academic Publishing, Australian National University, Canberra, pp. 397-429.

Cosgrove, R., Allen, J., Marshall, B., 1990. Palaeoecology and Pleistocene human occupation in south central Tasmania. Antiquity 64, 59-78.

Danzeglocke, U., Jöris, O., Weninger, B., 2010. CalPal-2007online. http://www.calpalonline.de/ (accessed 11.02.10).

Dawson, T.J., 1995. Kangaroos: Biology of the Largest Marsupials. In: Australian Natural History Series. University of New South Wales Press, Sydney.

DeNiro, M.J., 1985. Postmortem preservation and alteration of in vivo bone collagen isotope ratios in relation to palaeodietary reconstruction. Nature 317, 806-809. Diamond, J., 2008. The last giant kangaroo. Nature 454 (14), 835-836.

Driessen, M., 1988. Age structure and reproduction of Bennetts and Rufous Wallabies in Tasmania, Phase 1. A report funded by the Australian National Parks and Wildlife Service, Canberra.

Eggins, S., Grün, R., McCulloch, M., Pike, A., Chappell, J., Kinsley, L., Shelley, M. Murray-Wallace, C., Spötl, C., Taylor, L., 2005. In situ U-series dating by laserablation multi-collector ICPMS: new prospects for Quaternary geochronology. Quaternary Science Reviews 24, 2523-2538.

Eggins, S., Grün, R., Pike, A., Shelley, A., Taylor, L., 2003. ${ }^{238} \mathrm{U},{ }^{232} \mathrm{Th}$ profiling and Useries isotope analysis of fossil teeth by laser ablation-ICPMS. Quaternary Science Reviews 22, 1373-1382.

Field, J., 2006. The Megafauna extinction straw poll. Quaternary Australia 24 (1), 5.

Field, J., Fillios, M., Wroe, S., 2008. Chronological overlap between humans and megafauna in Sahul (Pleistocene Australia-New Guinea): a review of the evidence. Earth Science Reviews 89 (3-4), 97-115.

Fillios, M., Field, J., Charles, B., 2010. Investigating human and megafauna cooccurrence in Australian prehistory: mode and causality in fossil accumulations at Cuddie Springs. Quaternary International 211, 123-143.

Finlayson, H.H., 1927. Observations on the South Australian members of the subgenus Wallabia. Transactions of the Royal Society of South Australia 51, $363-377$.

Garvey, J., 2006. Preliminary zooarchaeological interpretations from Kutikina cave, South-West Tasmania. Australian Aboriginal Studies 1, 58-63.

Garvey, J., 2007. Surviving an Ice Age: the zooarchaeology from southwest Tasmania. Palaios 22, 583-585.
Garvey, J., 2010. Economic anatomy of the Bennett's wallaby (Macropus rufogriseus): implications for understanding human hunting strategies in late Pleistocene Tasmania. Quaternary International 211, 144-156.

Gaudzinski, S.F., Bittmann, W., Boenigk, M., Frechien, van Kolfschoten, T., 1996 Palaeoecology and archaeology of the Kärlich - Seeufer open-air site (Middle Pleistocene) in the Central Rhineland, Germany. Quaternary Research 46 319-334.

Gibson, N., Kirkpatrick, J.B., 1985. Vegetation and flora associated with localized snow accumulation at Mount Field West, Tasmania. Australian Journal of Ecology 10, 91-99.

Gill, E.D., Banks, M.R., 1956. Cainozonic history of Mowbray Swamp and other areas of north-western Tasmania. Records of the Queen Victoria Museum, Launceston $6,1-42$.

Goede, A., 1976a. Junee-Florentine trip report 20-21/11/76. Speleo Spiel 119, 5-6. Goede, A., 1976b. Cave numbering. Speleo Spiel 119, 4.

Goede, A., 1998. Quaternary studies of caves and coasts. Unpublished PhD thesis, School of Geography and Environmental Studies, vol. 1, University of Tasmania, Hobart

Goede, A., Bada, J., 1985. Electron spin resonance dating of Quaternary bone material from Tasmanian caves: a comparison with ages determined by aspartic acid racemization and $C^{14}$. Australian Journal of Earth Sciences 32, 155-162.

Goede, A., Murray, P., 1977. Pleistocene man in south central Tasmania: evidence from a cave site in the Florentine valley. Mankind 11, 2-10.

Goede, A., Murray, P., 1979. Late Pleistocene bone deposits from a cave in the Florentine Valley, Tasmania. Papers and Proceedings of the Royal Society of Tasmania 113, 39-52.

Grayson, D.K., Meltzer, D.J., 2003. A requiem for North American overkill. Journal of Archaeological Science 00, 1-9.

Grün, R., 2002. ESR dose estimation on fossil tooth enamel by fitting the natura spectrum into the irradiated spectrum. Radiation Measurements 35, 87-93.

Grün, R., 2006. Direct dating of human remains. Yearbook of Physical Anthropology $49,2-48$.

Grün, R., 2007. Electron spin resonance dating. In: Encyclopedia of Quaternary Science. Elsevier, Oxford, pp. 1505-1516.

Grün, R., 2008. Electron spin resonance (ESR) dating. In: Encyclopedia of Archeology. Elsevier, Oxford, pp. 1120-1129.

Grün, R., Katzenberger-Apel, O., 1994. An alpha irradiator for ESR dating. Ancient TL $12,35-38$.

Grün, R., Schwarcz, H.P., Chadam, J.M., 1988. ESR dating of tooth enamel: coupled correction for U-uptake and U-series disequilibrium. Nuclear Tracks and Radiation Measurements 14, 237-241.

Higham, T.F.G., Jacobi, R.M., Bronk Ramsey, C., 2006. AMS radiocarbon dating of ancient bone using ultrafiltration. Radiocarbon 48 (2), 179-195.

Hocking, G.J., Guiler, E.R., 1983. The mammals of the lower Gordon River region south-west Tasmania. Australian Wildlife Research 10, 1-23.

Horton, D.R., Murray, P., 1980. The extinct Toolach Wallaby (Macropus greyi) from a spring mound in north western Tasmania. Records of the Queen Victoria Museum. Launceston.

Hua, Q., Jacobsen, G.E., Zoppi, U., Lawson, E.M., Williams, A.A., Smith, A.M., McMann, M.J., 2001. Progress in radiocarbon target preparation at the ANTARES AMS centre. Radiocarbon 43 (2a), 275-282.

Jarman, P.J., Southwell, C.J., 1986. Grouping, associations, and reproductive strategies in Eastern Grey Kangaroos. In: Rubenstein, D.I., Wrangham, R.W. (Eds.) Ecological Aspects of Social Evolution: Birds and Mammals. Princeton University Press, Princeton, New Jersey, pp. 399-428.

Johnson, C.N., 1985. Ecology, social behaviour and reproductive success in the rednecked Wallaby. Unpublished Ph D thesis, University of New England, Armidale, New South Wales.

Johnson, C.N., 2006. Australia's Mammal Extinctions: a 50,000 Year History. Cambridge University Press.

Kiernan, K., Jones, R., Ranson, D., 1983. New evidence from Fraser cave for glacial age man in Southwest Tasmania. Nature 301, 28-32.

Kirkpatrick, J.B., 1986. Tasmanian alpine biogeography and ecology and interpretations of the past. In: Barlow, B.A. (Ed.), Flora and Fauna of Alpine Australasia. Ages and Origins. C.S.I.R.O., Melbourne.

Kirkpatrick, J.B., Folwer, M., 1998. Locating likely glacial forest refugia in Tasmania using palynological and ecological information to test alternative climatic models. Biological Conservation 85, 171-182.

Koch, P.L., Barnosky, A.D., 2006. Extinctions: state of the debate. Annual Review of Ecology, Evolution, and Systematics 37, 215-250.

Macphail, M.K., 1975. Late Pleistocene environments in Tasmania. Search 6 (7), 295-300

Macphail, M.K., 1979. Vegetation and climates in Southern Tasmania since the Last Glaciation. Quaternary Research 11, 306-341.

Marean, C.W., Cleghorn, N., 2003. Large mammal skeletal element transport: applying foraging theory in a complex taphonomic system. Journal of Taphonomy 1 (1), 15-42.

Marsh, R.E., 1999. Beta-gradient isochrons using electron paramagnetic resonance: towards a new dating method in archaeology. MSc thesis, McMaster University, Hamilton.

McIntosh, P.D., Price, D.M., Eberhard, R., Slee, A.J., 2009. Late Quaternary erosion events in lowland and mid-altitude Tasmania in relation to climate change and first human arrival. Quaternary Science Reviews 28 (2009), 850-872.

McWilliams, R., Allen, J., Cosgrove, R., Holdaway, S., 1999. Archaeological database. In: Report of the Southern Forests Archaeological Project, vol. 3. Archaeological 
Publications, Department of Archaeology, La Trobe University, Bundoora. CDROM.

Metcalfe, D., Barlow, K.R., 1992. A model for exploring the optimal tradeoff between field processing and transport. American Anthropologist 94, 340-356.

Miller, Gifford H., Fogel, Marilyn L., Magee, John W., Gagan, Michael K. Clarke, Simon J., Johnson, Beverly J., 2005. Ecosystem collapse in Pleistocene Australia and a human role in megafaunal extinction. Science 309, 287-290.

Miller, G.H., Magee, J.W., Johnson, B.J., Fogel, M.L., Spooner, N.A., McCulloch, M.T., Ayliffe, L.K., 1999. Pleistocene extinction of Genyornis newtoni: human impact on Australian megafauna. Science 283, 205-208.

Murray, P., Goede, A., Bada, J., 1980. Pleistocene human occupation at beginners luck Cave, Florentine Valley, Tasmania. Archaeology and Physical Anthropology in Oceania 15, 142-152.

Noetling, F., 1912. The occurrence of gigantic marsupials in Tasmania. In: Papers and Proceedings of the Royal Society Tasmania for 1911, pp. 124-133.

O'Connell, J., Hawkes, K., 1988. Hadza hunting, butchering, and bone transport and their archaeological implications. Journal of Anthropological Research 44 113-161.

O’Connell, J.F., Hawkes, K., Blurton Jones, N.G., 1990. Reanalysis of large animal body part transport among the Hadza. Journal of Archaeological Science 17, 301-316.

Pike-Tay, A., Cosgrove, R., Garvey, J., 2008. Systematic seasonal land use by late Pleistocene Tasmanian Aborigines. Journal of Archaeological Science 35 (9), 2532-2544.

Plomley, N.J.B., 1966. Friendly Mission: the Journals of George Augustus Robinson 1929-1834. Tasmanian Historical Society Research Association, Hobart.

Prescott, J.R., Hutton, J.T., 1994. Cosmic ray contributions to dose rates for luminescence and ESR dating: large depths and long-term time variations. Radiation Measurements 23, 497-500.

Prideaux, G.J., 2004. Systematics and evolution of the Sthenurine Kangaroos. In: Geological Sciences, vol. 146. University of California Publications. 1-623.

Roberts, R., Jacobs, Z., 2008. The lost giants of Tasmania. Australasian Science 29 (9), 14-17.

Roberts, Richard G., Flannery, T.F., Ayliffe, L.K., Yoshida, H., Olley, J.M., Prideaux, G.J., Laslett, G.M., Baynes, A., Smith, M.A., Jomes, R., Smith, B.L., 2001. New ages for the last Australian Megafauna: continent-wide extinction about 46,000 years ago. Science 292, 1888-1892.
Ross, J., 1830. Recollections of a short excursion to Lake Echo in March 1823. Hobart Town Almanac, pp. 85-122.

Scott, E.G.O., 1942a. Letter to Mr F. Archer 26th March, 1942. Queen Victoria Museum, Launceston, Tasmania.

Scott, E.G.O., 1942b. Letter to Dr A.B. Walkom 21st April 1942. Queen Victoria Museum, Launceston, Tasmania.

Scott, H.H., 1911. Natural history and osteology. Part 1. Nototherium tasmanicum sp. nov. Tasmanian Naturalist 2 (4), 64-68.

Scott, H.H., 1915. A monograph of Nototherium tasmanicum. Geological Survey Record No. 4. Government Printer, Hobart.

Sim, R., 1998. The Archaeology of Isolation? Prehistoric Occupation in the Furneaux Group of Islands, Bass Strait, Tasmania. Unpublished PhD Thesis, Department of Archaeology and Natural History, Australian National University, Canberra.

Strahan, R., 1983. The Australian Museum Complete Book of Australian Mammals. Angus and Robertson, Sydney.

Tanner, Z., Hocking, G., 2001. Status and Management of the Forester Kangaroo in Tasmania 2000. Nature Conservation Branch, Department of Primary Industries, Water and Environment, Hobart, Tasmania.

Tisnérat-Laborde, N., Valladas, H., Kaltnecker, E., Arnold, M., 2003. AMS radiocarbon dating of bones at LSCE. Radiocarbon 45 (3), 409-419.

Trueman, Clive N.G., Field, J., Dortch, J., Charles, B., Wroe, S., 2005. Prolonged coexistence of humans and megafauna in Pleistocene Australia. Proceedings of the National Academy of Science 102 (23), 8381-8385.

Turney, C., Flannery, T.F., Roberts, R.G., Reid, C., Fifield, L.K., Higham, T.F.G., Jacobs, Z., Kemp, N., Colhoun, E.A., Kalin, R.M., Ogle, N., 2008. Late-surviving megafauna in Tasmania, Australia, implicate human involvement in their extinction. Proceedings of the National Academy of Science 105 (34), 12150-12153.

Webb, S., 2008. Megafauna demography and late Quaternary climatic change in Australia: a predisposition to extinction. Boreas 37, 329-345.

Winterhalder, B., Lu, F., 1997. A forager-resource population ecology model and implications for indigenous conservation. Conservation Biology 11, 1354-1364.

Wroe, S., Field, J., 2006. A review of the evidence for a human role in the extinction of Australian megafauna and an alternative interpretation. Quaternary Science Reviews 25, 2692-2703.

Wroe, S., Field, J., Fullagar, R., Jermin, L.S., 2004. Megafaunal extinction in the late Quaternary and the global overkill hypothesis. Alcheringa 28, 291-331. 